\title{
Comparing the Effectiveness of Three Different Biorefinery Processes at Recovering Bioactive Products from Hemp (Cannabis sativa L.) Byproduct
}

\author{
Leonardo Setti $^{1} \cdot$ Seyedeh Parya Samaei ${ }^{2} \cdot$ Irene Maggiore $^{1} \cdot$ Lorenzo Nissen $^{3}$ (D) $\cdot$ Andrea Gianotti $^{2,3} \cdot$ Elena Babini $^{2}$
}

Received: 20 July 2020 / Accepted: 29 October 2020 / Published online: 11 November 2020

(C) The Author(s) 2020

\begin{abstract}
Hemp (Cannabis sativa L.) seeds are considered a nutritional powerhouse, rich in proteins and unsaturated fatty acids. The market for hemp seed food products is growing, due to the loosening of constraints in industrial cultivation. During the food processing chain, the external part of the seed is discarded, although it contains a significant amount of proteins. Converting this material into value-added products with a biorefinery approach could meet the ever-increasing need for sustainable protein sources while reducing food waste. In this study, creating value from hemp byproducts was pursued with three different approaches: (i) chemical extraction followed by enzymatic digestion, (ii) liquid fermentation by strains of Lactobacillus spp., and (iii) solid-state fermentation by Pleurotus ostreatus. The resulting products exhibited a range of in vitro antioxidant and antihypertensive activity, depending on the proteases used for enzymatic digestion, the bacterial strain, and the length of time of the two fermentation processes. These byproducts could be exploited as functional ingredients in the food, pharmaceutical, and cosmetic industries; the suggested biorefinery processes thus represent potential solutions for the development of other proteincontaining byproducts or wastes.
\end{abstract}

Keywords Protein hydrolysates $\cdot$ Lactobacillus spp. · Pleurotus ostreatus $\cdot$ Solid-state fermentation $\cdot$ ACE-inhibitory activity Antioxidant activity

\begin{tabular}{|c|c|}
\hline \multicolumn{2}{|c|}{ Abbreviations } \\
\hline 6BHI & L. fermentur \\
\hline AA & Ascorbic aci \\
\hline AAeq & Ascorbic aci \\
\hline \multirow{2}{*}{ ABTS } & 2,2,-Azino-b \\
\hline & (3-ethy \\
\hline $\mathrm{ACE}$ & Angiotensin \\
\hline Alc & Alcalase \\
\hline \multicolumn{2}{|c|}{$\begin{array}{l}\text { Lorenzo Nissen } \\
\text { lorenzo.nissen@unibo.it }\end{array}$} \\
\hline \multicolumn{2}{|c|}{$\begin{array}{l}\text { Leonardo Setti } \\
\text { leonardo.setti@unibo.it }\end{array}$} \\
\hline \multicolumn{2}{|c|}{$\begin{array}{l}\text { Seyedeh Parya Samaei } \\
\text { samaeiparya@gmail.com }\end{array}$} \\
\hline \multicolumn{2}{|c|}{ Irene Maggiore } \\
\hline $\begin{array}{l}\text { And } \\
\text { andr }\end{array}$ & otti \\
\hline
\end{tabular}

$\begin{array}{ll}\text { BSA } & \text { Bovine serum albumin } \\ \text { C1112 } & \text { L. rhamnosus C112 } \\ \text { C1272 } & \text { L. acidophilus C1272 } \\ \text { Chy } & \text { Chymotrypsin } \\ \text { DPPH } & \text { 1,1-Diphenyl-2-picrylhydrazyl } \\ \text { Fla } & \text { Flavourzyme } \\ \text { HPM } & \text { Hemp meal } \\ \text { HPB } & \text { Hemp bran }\end{array}$

1 CHIMIND (Department of Industrial Chemistry) Alma Mater Studiorum, University of Bologna, V.le Risorgimento 4, 40136 Bologna, Italy

2 DISTAL (Department of Agricultural and Food Sciences) Alma Mater Studiorum, University of Bologna, P.za G. Goidanich 60, 40122 Cesena, FC, Italy

3 CIRI (Interdepartmental Centre of Agri-Food Industrial Research), Alma Mater Studiorum, University of Bologna, Via Q. Bucci, 336, 47521 Cesena, FC, Italy 


$\begin{array}{ll}\text { HPBPI } & \text { Hemp bran protein isolate } \\ \text { L. } & \text { Lactobacillus } \\ \text { L98b } & \text { L. plantarum } 98 \mathrm{~b} \\ \text { LB325 } & \text { L. plantarum } 325 \\ \text { LB82 } & \text { L. plantarum LB82 } \\ \text { LC } & \text { L. paracasei LC } \\ \text { LCD1 } & \text { L. casei LCD1 } \\ \text { MR13 } & \text { L. fermentum MR13 } \\ \text { MRS } & \text { de Man-Rogosa-Sharpe } \\ \text { MW } & \text { Molecular weight } \\ \text { Neu } & \text { Neutrase } \\ \text { P. ostreatus } & \text { Pleurotus ostreatus } \\ \text { Pan } & \text { Pancreatin } \\ \text { Pep } & \text { Pepsin } \\ \text { PLH4 } & 4 \mathrm{~h} \text { P. ostreatus fermented sample } \\ \text { PLH9 } & 9 \mathrm{~h} \text { P. ostreatus fermented sample } \\ \text { PLH13 } & \text { 13 h } \text { P. ostreatus fermented sample } \\ \text { PLH17 } & \text { 17 } \text { P. } \text { ostreatus } \text { fermented sample } \\ \text { PRLF } & \text { L. fermentum } \text { PRLF } \\ \text { Pro } & \text { Protamex } \\ \text { SDS-PAGE } & \text { Sodium dodecyl } \\ & \text { sulfate-polyacrylamide gel } \\ & \text { electrophoresis } \\ \text { spp. } & \text { Species } \\ \text { SSF } & \text { Solid-state fermentation } \\ \text { Try } & \text { Trypsin }\end{array}$

\section{Introduction}

Agro-food industrial chains generate a large number of byproducts and waste, with negative environmental, economic, and social impacts (Torres-León et al. 2018). These materials often contain significant quantities of secondary chemical building blocks (such as proteins, polysaccharides, lipids, micronutrients, phytochemicals, and dietary fiber) which could be recovered by biorefinery processes. The everincreasing need for proteins of the food sector based on the continuous growth of the world population requires new sustainable protein sources due to depletion of renewable feedstocks, reduction in arable land, climate change, and environmental pollution.

Protein extraction from byproducts can be achieved using different techniques, like chemical extraction, liquid fermentation by microorganisms, and solid-state fermentation (SSF) by fungi (Baiano 2014). Chemical extraction is the most useful technique, taking advantage of the solubility of proteins at alkaline $\mathrm{pH}$. Further hydrolysis of protein extracts with enzymes, while keeping the nutritional value of protein isolates, can improve their functional properties and allow the acquisition of specific bioactivities related to the release of bioactive peptides. To date, protein hydrolysates with antioxidant, antihypertensive, anticancer, antimicrobial, hypocholesterolemic, immunostimulating, and other properties have been produced from a number of sources (Martínez-Alvarez et al. 2015; Rizzello et al. 2016). Similar results can be achieved by liquid fermentation using Lactobacillus spp., thanks to their safety, efficient proteolytic system, and ability to adapt to different environments and matrices (Rizzello et al. 2016). For example, lactobacilli fermentation can improve the procyanidins and antiradical activity of cocoa bean (Di Mattia et al. 2013), or can improve the prebiotic activity of fibers present in plant-based sources (Sánchez-Zapata et al. 2013; GarciaAmezquita et al. 2018; Nissen et al. 2020a). During fermentation, the biological activity of lactobacilli or the release of proteolytic enzymes into the media can change the nutritional and bioactive properties of the raw materials, producing peptides with various biological activities (Hafeez et al. 2014; Raveschot et al. 2018). Another biotransformation process is SSF by fungi; for example, mushrooms such as white-rot fungi are produced worldwide, both for their edible value and for their bio-compounds, which have medicinal properties. Recent studies have shown that it is possible to improve the quality (i.e., nutritional value and biological properties such as antioxidant) of cereals by applying SSF with mushrooms (Subramaniam et al. 2014; Zhai et al. 2015). Fungi through SSF are able to transform different wastes from industrial food products (Murthy and Naidu 2012; Nath et al. 2016). This biotechnology can be applied to the production of enzymes from agro-industrial wastes such as wheat bran, rice straw, banana waste, tea waste, and kinnow pulp (Oberoi et al. 2010). For example, xylanase can be produced by SSF on coffee byproducts (Murthy and Naidu 2012), or lipase can be produced from wheat industry byproducts (Treichel et al. 2010). Besides, other compounds than enzymes can be produced with SSF by fungi, likely optically pure L-lactic acid that can be obtained from whey byproduct of dairy industry (Taskin et al. 2012; Wu et al. 2011). SSF by fungi of whey, such as Aspergillus niger have received popularity for industrial glutamic acid production, while filamentous fungi for the production of lactobionic acid (Nath et al. 2016). SSF by fungi of apple pomace can be used to improve the mobilization of phenolic compounds, obtaining a product with superior antioxidant activity (Ajila et al. 2012). Bao et al. (2013) reported that the amount of crude proteins, crude fats, polysaccharides, reducing sugars, polyphenols, total amino acid, and adenosine significantly increased when rice was fermented with Pleurotus eryngii. Whiterot fungi are known to efficiently attack the lignocellulosic matrix by secreting specific extracellular oxidative and hydrolase enzymes (Abdel-Hamid et al. 2013), allowing the extraction of proteins present in the vegetable cell wall. In particular, Pleurotus ostreatus is able to produce specific enzymes through SSF processing of different solid agrofood wastes (Zilly et al. 2012; Fernández-Fueyo et al. 2014; Akpinar and Urek 2012). 
In the present work, we compared the effectiveness of these three bioprocesses at extracting and transforming the protein fraction of a byproduct generated in the hemp (Cannabis sativa L.) food processing chain. In the initial processing phase, hemp seeds are mechanically pressed, producing hemp meal (HPM) in the form of small cylindrical bars (along with hemp oil). These bars, after being ground, undergo a series of sieving steps to separate the small particles, the flour, from the large particles. This latter fraction, the hemp bran (HPB), is normally discarded or used for animal feed, despite its important protein content (Pojić et al. 2014). Recently a technological study has compared different mechanical pretreatments to improve ultrasonic extraction of polyphenols from hemp seed cake (Teh et al. 2014), but no literature is found over biotechnological approaches.

The three processes (alkaline extraction followed by enzymatic hydrolysis, liquid fermentation by Lactobacillus spp., and SSF by P. ostreatus) were optimized to recover HPB's protein fraction. The soluble proteins, antioxidant properties, and ACE-inhibitory activity in the resulting biorefinery products were evaluated and compared, in order to foresee their exploitation by the food, cosmetic, and pharmaceutical industries.

\section{Material and Methods}

\section{Material}

HPB, a byproduct remaining after mechanical pressing of hemp seeds and subsequent grinding and sieving, was supplied by a local company (Hemp Positive World, Cesena, Italy). Original hemp variety was Futura 75. General reagents and enzymes for enzymatic hydrolysis were analytical grade from Merck KGaA (Darmstadt, Germany). The o-aminobenzoylglycyl-p-nitro-L-phenylalanyl-L-proline (Abz-Gly-Phe(NO2)-Pro) and o-aminobenzoylglycine (Abz-Gly) were from Bachem Holding (Bubendorf, Switzerland). MRS broth (de Man-Rogosa-Sharpe) (dextrose 20\%; peptone 10\%; beef extract $8 \%$; sodium acetate $5 \%$; yeast extract $4 \%$; ammonium citrate $2 \%$; dipotassium phosphate $2 \%$; polysorbate $801 \%$; magnesium sulfate $0.2 \%$; manganese sulfate $0.05 \%$ ) was from Oxoid (Thermo Fisher Scientific, Waltham, MA, USA). SuperFi Platinum Taq was from Invitrogen (Thermo Fisher Scientific, Carlsbad, CA, USA). Pre-cast gels, the MW marker for sodium dodecyl sulfate-polyacrylamide gel electrophoresis (SDSPAGE), bovine serum albumin (BSA), and related reagents were from Bio-Rad (Hercules, CA, USA).
HPB Protein Extraction and Enzymatic Hydrolysis

\section{Protein Extraction and Evaluation of Total Protein Content}

Protein extraction from HPB was made following the procedure described by Tang et al. (2009). The milled hemp bran was mixed with distilled water in the ratio of $1: 20(\mathrm{w} / \mathrm{v})$ at room temperature, and the mixture was adjusted to $\mathrm{pH} 10.0$ with $2 \mathrm{~N} \mathrm{NaOH}$. After $1 \mathrm{~h}$ stirring, samples were centrifuged at $8000 \times g$ for $30 \mathrm{~min}$ at $4{ }^{\circ} \mathrm{C}$. The pellet was discarded, and the supernatant was collected and adjusted to $\mathrm{pH} 5.0$ with $2 \mathrm{~N}$ $\mathrm{HCl}$. Then, the isoelectric precipitate was collected by centrifugation $(8000 \times g$ for $10 \mathrm{~min})$, resuspended in deionized water, and homogenized. The suspension was adjusted to pH 7.0 with $2 \mathrm{~N} \mathrm{NaOH}$ and lyophilized in a Heto PowerDry LL300 freeze dryer (Thermo Fisher Corporation) to produce hemp bran protein isolate (HBPI).

In preliminary experiments for evaluating the efficiency of different extraction protocols, the effects of HPB defatting, alkali extraction time, and ultrasonic treatment of HPB were also evaluated. Briefly, HPB was defatted adding hexane to the bran in a ratio of 1:3, stirring at $250 \mathrm{rpm}$ for $30 \mathrm{~min}$, and centrifuging at $5000 \times \mathrm{g}$ for $10 \mathrm{~min}$ at room temperature. The procedure was repeated thrice and the defatted HPB was dried overnight, under the hood. In ultrasonic assisted method, HPB and distilled water were mixed in a ratio of 1:20 in an ice bath and $\mathrm{pH}$ was adjusted to 10 . Ultrasonication was performed using Hielscher UP400S (Hielscher Ultrasonic $\mathrm{GmbH}$, Teltow, Germany), at $100 \mathrm{~W}$ for $5,10,20$, and $30 \mathrm{~min}$. Removal of insoluble material and acid precipitation were made following the method of Tang et al. (2009), previously described.

The total protein content of HBPI was determined by the Kjeldahl method $(N=6.25)$, according to AOAC standard methods (Latimer 2016).

\section{Enzymatic Hydrolysis}

The HBPI was dissolved in deionized water $(1: 8, w / v)$ and hydrolyzed with 8 different enzymes in separate aliquots. The reactions with pepsin, trypsin, and pancreatin (enzyme concentration $1 \%, \mathrm{v} / \mathrm{v}$ ) were performed at $37^{\circ} \mathrm{C}$ and $\mathrm{pH} 2.0,7.0$, and 7.5 , respectively. Chymotrypsin $(1 \%, \mathrm{v} / \mathrm{v})$ and Flavourzyme $(0.2 \%, \mathrm{v} / \mathrm{v})$ treatments were made at $40{ }^{\circ} \mathrm{C}$ and pH 8.5 and 6.0, respectively. Hydrolysis with Alcalase (2\%, $\mathrm{v} / \mathrm{v})$, Protamex $(1 \%, \mathrm{v} / \mathrm{v})$, and Neutrase $(3 \%, \mathrm{v} / \mathrm{v})$ were performed at $50{ }^{\circ} \mathrm{C}$ and $\mathrm{pH} 8.0,7.0$, and 7.0, respectively. After 2-h incubation, enzymes were inactivated by heating at $85{ }^{\circ} \mathrm{C}$ for $15 \mathrm{~min}$. After cooling down to room temperature, solutions were centrifuged at $14000 \times g$ for $10 \mathrm{~min}$, and supernatants were collected and stored at $-80{ }^{\circ} \mathrm{C}$ for further analysis. The codes of the samples obtained by enzymatic treatments are reported in Online Resource 1. 


\section{Bacterial Fermentation of HPB}

For bacterial hydrolysis, ten different strains of Lactobacillus spp. were selected in a first fermentation (screening fermentation), including $L$. plantarum LB82, 98b, and 325, L. casei LCD1, L. paracasei LC, L. acidophilus C1272, L. fermentum PRLF, MR13, and BHI6, and L. rhamnosus C1112. All these bacterial strains belong to the microbial collection of the Department of Agricultural and Food Sciences of the University of Bologna (Italy), and have been previously isolated from sourdough and extensively studied (Babini et al. 2017; Taneyo-Saa et al. 2018; Taneyo-Saa et al. 2019; Nissen et al. 2019; Nissen et al. 2020a; Babini et al. 2020). Bacteria were revived from $-80{ }^{\circ} \mathrm{C}$ glycerol stock by two successive growths in MRS broth (Oxoid, Thermo Fisher Scientific, Waltham, MA, USA) at $37{ }^{\circ} \mathrm{C}$ for at least $24 \mathrm{~h}$. Afterwards, for each bacterial strain, an inoculum of $\log _{10} 7 \mathrm{CFU} / \mathrm{mL}$ was used to hydrolyze independently two sterilized $\left(121^{\circ} \mathrm{C}\right.$ and 1 bar for $15 \mathrm{~min}$ ) HPB/water suspensions (1:6 and 1:12 w/v). Incubations were made in $50-\mathrm{mL}$ volumes at $37^{\circ} \mathrm{C}$ for $24 \mathrm{~h}$.

The best performer strains of Lactobacillus spp. on the best sterile HPB/water suspension from the screening fermentation (L. plantarum 98b, L. fermentum 325, and L. rhamnosus C1112) were applied in a second fermentation (process fermentation), on 1:6 (w/v) sterile HPB/water suspension. These three strains and a pool of them were employed at a concentration of $\log _{10} 7 \mathrm{CFU} / \mathrm{mL}$ to ferment the $\mathrm{HPB} /$ water suspension at $37^{\circ} \mathrm{C}$ up to $72 \mathrm{~h}$.

Prior, over, and after both the screening and the process fermentations, $\mathrm{pH}$ values and bacterial growths were recorded. Not-inoculated sterile HPB/water suspensions were used as controls. Two biological replicates and two independent experiments were performed.

A complete list of bacterial strains used for the first and the second fermentation and their codes are reported in Online Resource 1.

\section{$\mathrm{pH}$ Values of Bacterial Fermented HPB}

The $\mathrm{pH}$ levels of bacterial fermented HPB/water suspensions were determined with a $\mathrm{pH}$ meter (Crison, Alella, Spain) at $20{ }^{\circ} \mathrm{C}$, appropriately calibrated with three standard buffer solutions at $\mathrm{pH} 9.21,4.00$, and 2.00. The $\mathrm{pH}$ values were measured in duplicate at different times, prior, over, and after the process.

\section{Bacterial Cell Measurement}

Bacterial quantification was obtained by both culturedependent and culture-independent protocols. The first consisted in plating on selective MRS agar supplemented with $0.05 \mathrm{~g} / \mathrm{L}$ L-cysteine serial dilutions $(\mathrm{NaCl} 0.9 \%, \mathrm{w} / \mathrm{v})$ of the samples, then incubated for $24 \mathrm{~h}$ at $37{ }^{\circ} \mathrm{C}$. Values were expressed as $\log _{10} \mathrm{CFU} / \mathrm{mL}$. Culture-independent quantifications were obtained by qPCR with the SYBR Green I chemistry applying genus-specific primers as Lac1 for Lactobacillus spp. (forward: 5'-GCAGCAGTAGGGAA TCTTCCA-3' and reverse: 5'-GCATTYCACCGCTA CACATG-3') (Castillo et al. 2006). Genetic standards were prepared from relative PCR amplicons from DNA of pure cultures of the target bacteria using a Pro-Flex PCR apparatus (Applied Biosystem, Foster City, CA, USA) as described previously (Nissen et al. 2019, 2020a, b). Bacterial DNA extraction and qPCR reactions were performed according to previous protocols employing a RotorGene 6000 (Qiagen, Hilden, Germany) (Nissen et al. 2019, 2020a, b). Quantification results are reported as the means of the values of the two techniques employed and expressed as $\log _{10}$ cells $/ \mathrm{mL}$ (Nissen et al. 2019, 2020a, b). Parameters of successful reactions and appropriate quantifications of qPCR are reported in Online Resource 5.

\section{P. ostreatus SSF on HPB}

\section{SFF Process}

Fifty grams of hemp bran was placed in a 500-mL Pyrex bottle with a cotton cap, wetted with $15 \mathrm{~mL}$ of potassium phosphate buffer $0.1 \mathrm{M} \mathrm{pH} 5.8$ and sterilized by autoclaving at $120{ }^{\circ} \mathrm{C}$ for $20 \mathrm{~min}$. This substrate was inoculated with $8.5 \mathrm{~g}$ of $P$. ostreatus (commercial strain purchased from Azienda Agricola Funghi Mara, BO) grown on malt extract agar (Masutti et al. 2015). The fermentation was made at $27{ }^{\circ} \mathrm{C}$, in the dark for a period of 17 days. The fermentation process was monitored sampling after $4,9,13$, and 17 days. The samples were recovered under sterile conditions by adding in the fermenter a specific quantity of buffer, necessary to collect the enzymes produced during the SSF process. The "waste water," the portion of solution not adsorbed onto the substrate and containing the enzymes, was withdrawn by a sterile pipette. Each sample was centrifuged for $20 \mathrm{~min}$ at $4255 \times g$ to remove the solid fraction and lyophilized in a Coolsafe 55-4 freeze dryer (Scanvac, Lillerod, DK). Samples collected after 4, 9, 13, and 17 days of SSF were named, respectively, PLH4, PLH9, PLH13, and PLH17 (Online Resource 1).

\section{Determination of Cellulase, Xylanase, Pectinase, and Amylase Activities}

The cellulase, xylanase, and pectinase activities were determined as reducing sugars following the method described by Bailey et al. (1992), using cellulose filter paper (ca. $50 \mathrm{mg}$ ), xylose from beechwood, pectin from apple, and starch from potato as respective substrates. The reaction for cellulase activity was carried out at $50^{\circ} \mathrm{C}$ for $1 \mathrm{~h}$, in citrate buffer $0.05 \mathrm{M}$ 
at $\mathrm{pH}$ 4.8. Reactions for xylanase, pectinase, and amylase activities were carried out at $30{ }^{\circ} \mathrm{C}$ for $3 \mathrm{~min}$ at variable $\mathrm{pH}$ (3-6) in citrate buffer $0.05 \mathrm{M}$. The glucose, xylose, and galacturonic acids released were detected by a UV-Vis spectrophotometer (UVIKON 923, Biotech Kontron, Augsburg, Germany) at $550 \mathrm{~nm}$. The total activities were expressed as $\mu \mathrm{mol}$ of monomer released per minute. Each test was repeated three times for each sample. Concerning the assays conducted at variable $\mathrm{pH}$, only the activities at optimum $\mathrm{pH}$ were reported: $\mathrm{pH}=6$ for xylanase, $\mathrm{pH}=4$ for pectinase, and $\mathrm{pH}=5$ for amylase (Table 2).

\section{Determination of Peroxidase and Laccase Activities}

The peroxidase activity was determined following the method described by Setti et al. (1998). Briefly, it was employed an oxidative coupling reaction of MBTH (3-methyl 2benzothiazolinone hydrazone) in the presence of hydrogen peroxide and methoxyphenols at $30{ }^{\circ} \mathrm{C}$, in $25 \mathrm{mM}$ sodium phosphate buffer at $\mathrm{pH}$ 6.5. The reaction produces a redcolored azo-dye compound, then detected by a UV-Vis spectrophotometer (UVIKON 923, Biotech Kontron), at $502 \mathrm{~nm}$.

The laccase activity was determined following the method described for the peroxidase activity, but without hydrogen peroxide (Setti et al. 1999). The total activities were expressed as $\mu \mathrm{mol} / \mathrm{min}$ of MTBH. Each test was repeated three times for each sample.

\section{Determination of Arylesterase Activity}

The arylesterase activity was determined according to the method of Giuliani et al. (2001) with slight modifications. In particular, $0.9 \mathrm{~mL}$ of $100 \mathrm{mM}$ sodium phosphate buffer $\mathrm{pH}$ $6.0,0.1 \mathrm{~mL}$ of methyl ferulate or methyl caffeate, and $0.05 \mathrm{~mL}$ of the extract were mixed in a quartz cuvette. Immediately after adding the extract, the absorbance decrement at $335 \mathrm{~nm}$ was measured in a spectrophotometer (UVIKON 923, Biotech Kontron) for a time needed to detect the disappearance of methyl ferulate or methyl caffeate. These measurements were conducted three times on each sample. The activities were expressed in $\mu \mathrm{mol} / \mathrm{min}$ of methyl ferulate and methyl caffeate hydrolyzed.

\section{Determination of Protease Activity}

The protease activity was estimated by the method described by Kunitz (1947) with slight modification. A total of $1 \mathrm{~mL}$ of enzyme solution was added to $1 \mathrm{~mL}$ of casein $2 \%(\mathrm{w} / \mathrm{v})$ in $0.1 \mathrm{M}$ sodium phosphate buffer at variable $\mathrm{pH}$ (6-9); each mixture was incubated at $37^{\circ} \mathrm{C}$ for $1 \mathrm{~h}$ and the reaction was stopped by adding $2 \mathrm{~mL}$ of TCA $10 \%(\mathrm{w} / \mathrm{v})$. The samples were centrifuged for $10 \mathrm{~min}$ at $8000 \times \mathrm{g}$ and for each supernatant, the tyrosine equivalents released were detected by a UV-Vis spectrophotometer (UVIKON 923, Biotech Kontron) at $280 \mathrm{~nm}$.
The activity was expressed in $\mu \mathrm{mol}$ tyrosine/min and the one at optimum pH 9 was reported (Table 2). Each measurement was conducted in triplicate on the same sample.

\section{Evaluation of Soluble Protein Content}

Soluble protein concentration was evaluated by Bradford assay using the Quick Start Bradford Protein Assay kit from Bio-Rad (Hercules, CA, USA). Absorbance of samples after addition of the dye was measured after 5-10 $\mathrm{min}$, at $595 \mathrm{~nm}$ in a microplate reader SPARK 10M (TECAM, Switzerland). The standard curve was obtained with bovine serum albumin (BSA) from 0.5 to 10 $\mu \mathrm{g} / \mathrm{mL}$. Results were expressed in $\mu \mathrm{g} / \mathrm{mL}$, as mean \pm SEM (standard error of mean) of three replicates.

\section{Protein Pattern Analysis by SDS-PAGE}

Protein pattern was analyzed on $4 \%$ stacking and $14 \%(\mathrm{v} / \mathrm{v})$ resolution Tris SDS-polyacrylamide gels using MiniPROTEAN® equipment from Bio-Rad (Hercules, CA, USA). Protein ladder of 10-200 kDa was used as molecular weight (MW) marker.

\section{Antioxidant Activity Assays}

Antioxidant activity was analyzed by ABTS (2,20-azino-bis3-ethylbenzothiazoline-6-sulfonic acid) radical scavenging assay, ferrous ion-chelating ability assay, and ferric reducing antioxidant power (FRAP) assay. All analyses were performed on a microplate scale, and absorbance was measured in a microplate reader SPARK 10M (TECAM, Switzerland). Results were expressed as mean values of three replicates. The ABTS (2,20-azino-bis-3-ethylbenzothiazoline-6-sulfonic acid) scavenging activity was determined according to the procedure of Re et al. (1999). Briefly, an ABTS stock solution ( $7 \mathrm{mM}$ in $2.45 \mathrm{mM} \mathrm{K}_{2} \mathrm{~S}_{2} \mathrm{O}_{8}$ ) was diluted with sodium acetate $20 \mathrm{mM} \mathrm{pH} 4.5$, to reach an absorbance of $0.70 \pm 0.02$ at 734 $\mathrm{nm}$. This solution $(198 \mu \mathrm{L})$ and the sample $(2 \mu \mathrm{L})$ were mixed and incubated at room temperature in the dark for $30 \mathrm{~min}$. The absorbance was measured at $734 \mathrm{~nm}$. The results were expressed as mg AA eq/ $1 \mathrm{~L}$ of sample solution by means of a dose-response calibration curve of ascorbic acid (AA) at concentration from 0 to $5 \mathrm{mg} / \mathrm{L}$. Ferrous ion-chelating activity was measured according to the method reported by Tang et al. (2009). Sample aliquots $(25 \mu \mathrm{L})$ at different concentrations were mixed with $100 \mu \mathrm{L}$ of $50 \mu \mathrm{M}$ ferrous sulfate $\left(\mathrm{FeSO}_{4}\right)$ and $100 \mu \mathrm{L}$ of $300 \mu \mathrm{M}$ ferrozine. After incubation at room temperature for $10 \mathrm{~min}$, the absorbance of solutions was measured at $562 \mathrm{~nm}$. The results were expressed as $\mu \mathrm{g}$ EDTA eq/ $\mathrm{mL}$ of sample solution by means of a dose-response calibration curve of EDTA (from 0 to $10 \mu \mathrm{g} / \mathrm{L}$ ). The FRAP assay was performed following the method of Benzie and Strain (1996), based on the reduction of a ferric-tripyridyltriazine complex to 
its ferrous, colored form in the presence of antioxidants. Briefly, the FRAP reagent was prepared freshly mixing 1 $\mathrm{mL}$ of a 10 - $\mathrm{mM}$ TPTZ $(2,4,6$ - tripyridy-s-triazine) solution in $40 \mathrm{mM} \mathrm{HCl}, 1 \mathrm{~mL}$ of $20 \mathrm{mM} \mathrm{FeCl}_{3}$, and $10 \mathrm{~mL}$ of $300 \mathrm{mM}$ acetate buffer, $\mathrm{pH}$ 3.6. Aliquots of $10 \mu \mathrm{L}$ of sample were mixed with $300 \mu \mathrm{L}$ FRAP reagent and the absorbance of reaction mixture was measured at $593 \mathrm{~nm}$ after incubation at room temperature for $10 \mathrm{~min}$. AA at different concentrations in the range from 0 to $10 \mu \mathrm{M}$ was used as standard solution. Results were expressed as the volume of antioxidants having a ferric reducing ability equivalent to that of AA.

\section{ACE-Inhibitory Activity Assay}

Inhibition of angiotensin I-converting enzyme was determined through a fluorimetric assay using oaminobenzoylglycyl- $P$-nitro- $L$-phenylalanyl- $L$-proline (AbzGly-Phe(NO2)-Pro) as substrate (Sentandreu and Toldra 2006). The assay was performed under the following conditions: $50 \mu \mathrm{L}$ of sample were mixed with $50 \mu \mathrm{L}$ ACE solution $7.5 \mu \mathrm{g} / \mathrm{mL}$ and pre-incubated at $37^{\circ} \mathrm{C}$ for $10 \mathrm{~min}$. The reaction was started by addition of $200 \mu \mathrm{L}$ of $0.45 \mathrm{mM}$ Abz-GlyPhe(NO2)-Pro dissolved in $150 \mathrm{mM}$ Tris buffer, $\mathrm{pH}$ 8.3, containing $1.125 \mathrm{M} \mathrm{NaCl}$. The reaction mixture was incubated at $37^{\circ} \mathrm{C}$ for $30 \mathrm{~min}$ and the fluorescence, generated by the release of the Abz-Gly group, was measured in a fluorometer microplate reader SPARK 10M (TECAN, Switzerland), using excitation and emission wavelengths of 355 and $405 \mathrm{~nm}$, respectively. Different concentrations of oaminobenzoylglycine (Abz-Gly) in the range of 5-30 $\mu \mathrm{M}$ were used to obtain the reference curve. All analyses were performed in triplicate. The $\mathrm{IC}_{50}$ values were determined using nonlinear regression analysis, fitting the spectrophotometric data with the log (inhibitor) vs. response model generated by GraphPad Prism 6.0 (GraphPad Software, San Diego, CA, USA).

\section{Statistical Analysis}

Statistical tests were performed using the SPSS software (IBM Corp, Armonk, NY, USA). Statistical significance of differences among several means was determined using one-way analysis of variance ANOVA with Duncan test, with a significant level of $P<0.05$. Post hoc Tukey's HSD test was performed with Statistica 8.0 (Tibco Inc., Palo Alto, CA, USA).

\section{Results and Discussion}

The byproduct (HPB), used in the present work, was coming from the refining process of HPM through a $0.35-\mu \mathrm{m}$ sieve, to obtain type 2 semi-wholemeal flour. This material represents about the $10 \%(\mathrm{w} / \mathrm{w})$ of the seed, which means that about $10 \%$ of hemp seed is normally discarded during the food processing chain. The protein content of HPB was $20.63 \pm 0.91 \%$ $(\mathrm{w} / \mathrm{w})$ in dry matter, much higher compared to the amount measured by Pojić et al. (2014) in an equivalent fraction of HPM $(10.6 \pm 0.91 \%, w / w$, in dry matter). This difference can be related to the variability of protein content in the whole seed (20-25\% w/w, in dry matter) and in the HPM (30-50\%, $\mathrm{w} / \mathrm{w}$ in dry matter), depending on the variety of hemp and the oil extraction procedure (cold pressing or solvent) and efficiency (Malomo et al. 2014).

\section{Protein Extraction and Enzymatic Hydrolysis of HPBPI}

Protein extraction was obtained by the aqueous alkaline extraction method followed by isoelectric precipitation. In order to optimize the process, different extraction times were evaluated as well as preliminary defatting of the substrate, and the addition of an ultrasonication step for different times, after alkaline extraction (Online Resource 4). HPBPI from nondefatted HPB, obtained with alkali exposure time of $1 \mathrm{~h}$, contained the highest amount of soluble proteins (27.45 $\mathrm{g} / \mathrm{L}$ ). This sample was therefore used for hydrolysis reactions with 8 different enzymes, which were performed in specific $\mathrm{pH}$ and temperature conditions. Reaction time was $2 \mathrm{~h}$ as the maximum hydrolytic activity is usually reached after 2 -h incubation, as reported for a hemp protein isolate digested by six different proteases (Tang et al. 2009). The efficacy of the hydrolytic processes was checked analyzing the amount of soluble proteins released from the matrix and the protein/ peptide profile of hydrolysates on SDS-PAGE (the "Protein Solubility and Profile of Biorefinery Products" section).

\section{Screening Fermentation of HPB by Ten Strains of Lactobacillus Spp.}

\section{Preliminary Screening of Lactobacillus Spp. Strains}

Screening fermentation was made to select the best combinations among ten different Lactobacillus spp. strains and two HPB/water suspensions (w/v). pH results (Online Resource 2) showed that the two HPB suspensions were similarly subjected to significant acidification already after $6 \mathrm{~h}$, especially when $\mathrm{C} 1112$ and $98 \mathrm{~b}$ were used $(P<0.05)$. Besides, this trend was kept up to $24 \mathrm{~h}$ and the $\mathrm{C} 1112$ was the best performer $(\mathrm{pH}$ $4.12 \pm 0.07)$. However, the $\mathrm{pH}$ decrease was less than expected for a Lactobacillus spp. fermentation on a plant-based substrate, probably due to a buffering effect exerted by HPB. For example, sauerkrauts are acidified by lactic acid bacteria from an initial $\mathrm{pH}$ around 6.8 down to $\mathrm{pH}$ values minor than 4 after $12 \mathrm{~h}$ (Wiander and Korhonen 2011), or similar results were obtained by Fonteles et al. (2012) that after $24 \mathrm{~h}$ of fermentation of cantaloupe juice with $L$. casei, NRRL B-442 reached $\mathrm{pH}$ lower than 3.5. 
qPCR reactions averagely resulted of $R=0.9968$ and of $R^{2}=$ 0.9936 , with an efficiency of $69 \%$, and the same melt temperature specificity at $87{ }^{\circ} \mathrm{C}$ (Online Resource 5). Quantifications showed no significant differences between 1:12 and 1:6 (w/v) HPBI suspensions $(P>0.05)$. In detail, the best output was reached on 1:6 (w/v) suspension by LB325 and MR13 that grew up to $\log _{10} 12.25 \pm 0.09$ and $\log _{10} 12.71 \pm 0.26$ cells $/ \mathrm{mL}$, respectively (Online Resource 2 ).

\section{Process Fermentation of HPB by Selected Lactobacillus Spp. Strains}

Process fermentation was carried out inoculating a 1:6 (w/v) sterile HPB/water suspension with the three most competitive Lactobacillus spp. strains resulted from the screening fermentation. Two were selected for their top growth values (LB325, MR13), while a third for its top acidification performance (C1112). In addition, a pool of these three strains was assayed as the fourth inoculum. In this second part, the ratio HPB/ water suspension of 1:6 (w/v) was chosen. The starting inocula and the incubation conditions were the same of the screening part, but fermentation was extended up to $72 \mathrm{~h}$. Results for $\mathrm{pH}$ measurements (Table 1) indicated that each inoculum was able to lower the $\mathrm{pH}$ of more than 1 unit at the earl time point, and the top acidification was recorded after $48 \mathrm{~h}$ by $\mathrm{C} 1112$ with $\mathrm{pH}$ value of $4.21 \pm 0.02$. Considering the overall fermentation time, MR13 hit the larger delta of $2.26 \mathrm{pH}$ unit (Fig. 1a). Results from Lactobacillus spp. quantification (Table 1) indicated that the maximum growth was reached by the bacterial pool at the endpoint, attaining at $\log _{10} 12.64 \pm 0.28$ cells $/ \mathrm{mL}$ with a delta value of $\log _{10} 6.66$ cells $/ \mathrm{mL}$ (Fig. 1b). The growth of $\mathrm{C} 1112$ and MR13 strains recorded maximum levels after $48 \mathrm{~h}$, but declined before the endpoint. However, each single inoculum showed a very intensive growth between 6 and $48 \mathrm{~h}$ and reached a growth plateau from $48 \mathrm{~h}$ to the end of incubation (Table 1). The high growth of these strains could be due even to a possible buffering capacity of the matrix. In fact, even at the endpoint, the $\mathrm{pH}$ had a limit value of $4.31 \pm$ 0.04 , as that recorded by MRI3. To our knowledge, there are no reports in literature about any Lactobacillus spp. growing more than $\log _{10} 12.71$ cells $/ \mathrm{mL}$ for more than $48 \mathrm{~h}$. For example, in Fonteles et al. (2012), after $20 \mathrm{~h}$ of cantaloupe juice fermentation by L. casei, NRRL B-442 reached just $\log _{10}$ 8.39 CFU/mL. Nwamaioha and Ibrahim (2017) have demonstrated that L. reuteri 20016 and L. rhamnosus ATCC 53103 can grow up to $\log _{10} 9 \mathrm{CFU} / \mathrm{g}$ on MRS in anaerobic conditions and at $42{ }^{\circ} \mathrm{C}$ for $72 \mathrm{~h}$. Other authors, in the attempt to optimize the components of MRS to achieve massive growth of L. plantarum JNU 2116, reached $\log _{10} 9.15 \mathrm{CFU} / \mathrm{g}$ in aerobic conditions at $37^{\circ} \mathrm{C}$ for $48 \mathrm{~h}$ (Yoo et al. 2018). These results demonstrated the potential of $\mathrm{HMB}$ as a good substrate to deliver high amounts of metabolites (including peptides) without inhibition of Lactobacillus spp. growth.

\section{SSF on HPB with $P$. ostreatus}

SSF on HPB with $P$. ostreatus was carried out to stimulate the overexpression of specific enzymatic activities capable of doing the demolition of hemp cell wall, delignifying the hemp bran and hydrolyzing its carbohydrate polymers to encourage the protein extraction. As Masutti et al. (2012) showed that increasing SSF enzyme collection frequency brought to a greater production of enzymes, we decided to collect samples of enzymes produced with a frequency of 4 days of SSF and the total enzymatic activities were determined as concentration per $\mathrm{mL}$ of waste water collected at different $\mathrm{pH}$ (Table 2). After 4 days of fermentation, a relevant pectinase activity appeared as a consequence of the chemical structure characterizing the wall cell plant of the dicotyledons such as hemp plant. In these wall cell plants, the pectic chains surround the hemicellulose and cellulose network and the hydrolysis of these chains can make the fibers located below, more susceptible toward a further hydrolase action (Hatfield 1993). In comparison, Zilly et al. (2012) reached a higher pectinase activity $(620 \mathrm{U} / \mathrm{L})$ after 14 days of $P$. ostreatus SFF on passion fruit waste that more than fibers have a superior content of sugars than hemp. The production of significant amylasic and xylanasic activities was observed after 9 days of fermentation evidencing the presence of starch as well as arabinoxylane in the hemp bran. Our results about amylase and xylanase are
Table $1 \mathrm{pH}$ and $\log _{10}$ cells $/ \mathrm{mL}^{1}$ of cultures of Lactobacillus spp. (LB325, C1112, MR13, and their pool) on hemp bran/water suspension 1:6 (w/v), during process fermentation. Means with different letters are statistically significant by post hoc Tukey's HSD test $(P<0.05)$. Means with different symbols are statistically significant by post hoc Tukey's HSD test $(P<0.05)$

\begin{tabular}{lllllll}
\hline Samples & & $0 \mathrm{~h}$ & $6 \mathrm{~h}$ & $24 \mathrm{~h}$ & $48 \mathrm{~h}$ & $72 \mathrm{~h}$ \\
\hline LB325 & $\mathrm{pH}$ & $6.59 \pm 0.05^{*}$ & $5.45 \pm 0.10^{* *}$ & $4.43 \pm 0.08^{\dagger}$ & $4.39 \pm 0.02^{\dagger}$ & $4.56 \pm 0.04^{\dagger}$ \\
& Log cells $/ \mathrm{mL}$ & $5.95 \pm 0.08^{\mathrm{a}}$ & $7.88 \pm 0.09^{\mathrm{b}}$ & $10.41 \pm 0.31^{\mathrm{c}}$ & $11.78 \pm 0.35^{\mathrm{d}}$ & $12.13 \pm 0.19^{\mathrm{e}}$ \\
C1112 & $\mathrm{pH}$ & $6.50 \pm 0.03^{*}$ & $5.30 \pm 0.09^{* *}$ & $4.12 \pm 0.07^{\$}$ & $4.21 \pm 0.04^{\$}$ & $4.51 \pm 0.04^{\dagger}$ \\
& Log cells $/ \mathrm{mL}$ & $5.97 \pm 0.05^{\mathrm{a}}$ & $7.94 \pm 0.16^{\mathrm{b}}$ & $10.42 \pm 0.11^{\mathrm{c}}$ & $11.82 \pm 0.29^{\mathrm{d}}$ & $11.72 \pm 0.14^{\mathrm{d}}$ \\
MR13 & $\mathrm{pH}$ & $6.62 \pm 0.01^{*}$ & $5.24 \pm 0.09^{\dagger}$ & $4.43 \pm 0.08^{\dagger}$ & $4.35 \pm 0.04^{\dagger}$ & $4.36 \pm 0.04^{\dagger}$ \\
& Log cells $/ \mathrm{mL}$ & $5.94 \pm 0.08^{\mathrm{a}}$ & $9.33 \pm 0.14^{\mathrm{c}}$ & $10.81 \pm 0.32^{\mathrm{d}}$ & $12.37 \pm 0.23^{\mathrm{e}}$ & $12.29 \pm 0.05^{\mathrm{e}}$ \\
Pool & $\mathrm{pH}$ & $6.49 \pm 0.02^{*}$ & $5.82 \pm 0.08^{* *}$ & $4.59 \pm 0.04^{\dagger}$ & $4.39 \pm 0.05^{\dagger}$ & $4.63 \pm 0.04^{\dagger}$ \\
& Log cells $/ \mathrm{mL}$ & $5.98 \pm 0.04^{\mathrm{a}}$ & $8.35 \pm 0.25^{\mathrm{b}}$ & $10.85 \pm 0.32^{\mathrm{d}}$ & $11.73 \pm 0.35^{\mathrm{d}}$ & $12.64 \pm 0.28^{\mathrm{e}}$ \\
\hline
\end{tabular}


a

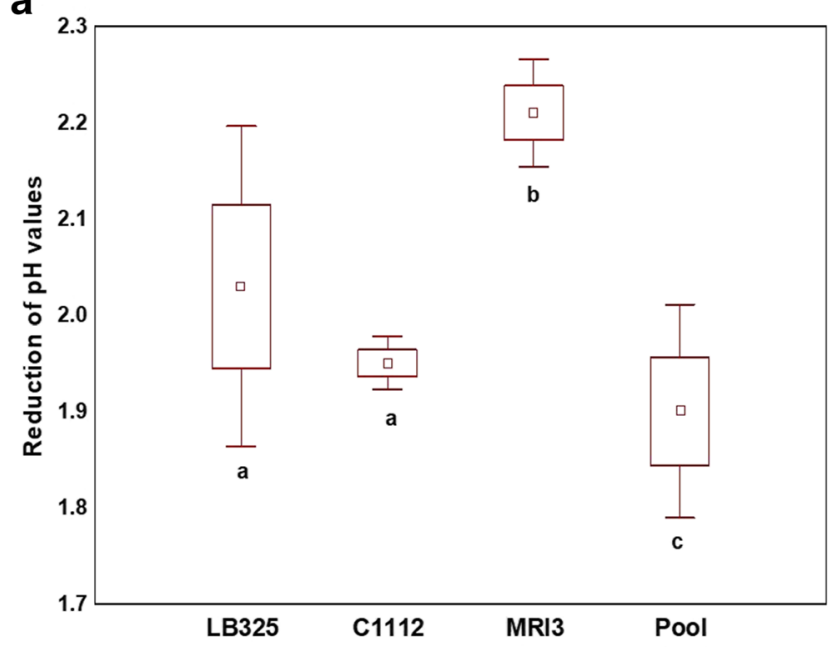

b

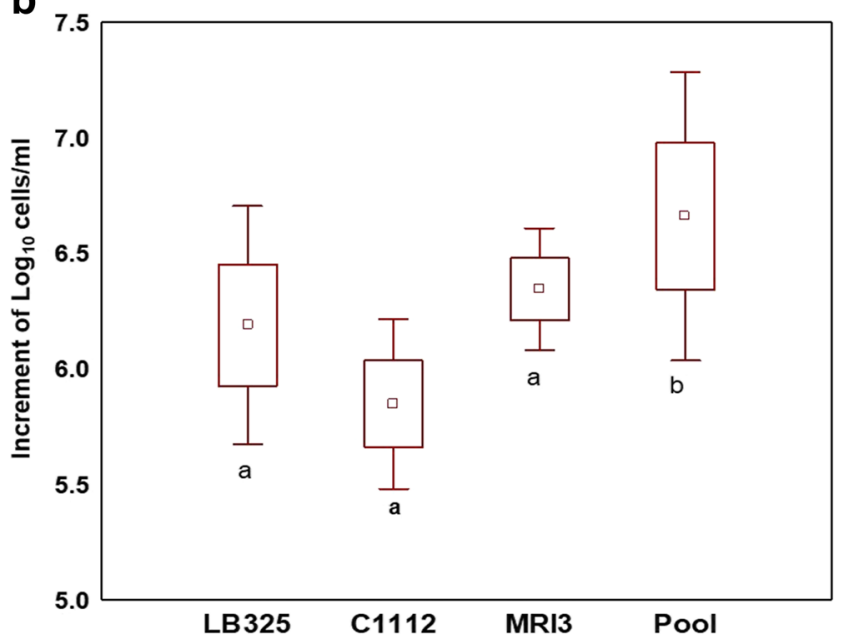

Fig. 1 Plots of mean values of a delta $\mathrm{pH}$ and $\mathbf{b}$ delta $\log _{10}$ cells $/ \mathrm{mL}$ of Lactobacillus spp. strains on hemp bran/water suspension 1:6 (w/v) during process fermentation. Marker: mean value; box: mean \pm standard deviation; whiskers: mean $\pm 1.96 *$ standard deviation. ${ }^{\mathrm{a}-\mathrm{c}}$ Means with different letters are statistically significant by post hoc Tukey's HSD test $(P<0.05)$ better than what obtained by Zilly et al. (2012) after 14 days of $P$. ostreatus SSF on wheat bran, accounting for 67 and $500 \mathrm{U} / \mathrm{L}$, respectively. Peroxidase activity appeared, then followed by laccase activity after 9 days which was a symptom of the fungal attack of lignin (Dashtban et al. 2010), since it is the more external structure of seed hull. Considering peroxidase and laccase, the outputs that we obtained showed for the former a minor activity in comparison to SSF by $P$. ostreatus on both wheat bran $(63 \mathrm{U} / \mathrm{L})$ and passion fruit wastes $(150 \mathrm{U} / \mathrm{L})$ almost at the same time point, but a larger activity for the latter already after 9 days (Zilly et al. 2012). Caffeoyl and feruloyl arylesterase activities were slightly produced remaining quite constant during all the period of the SSF even if the presence of caffeic and ferulic acid derivatives is common and in high quantity in monocotyledon spp. seed bran (Tetlow and Emes 2017; Peanparkdee et al. 2017). Arylesterase broke down the bounds between lignin and hemicellulose (Ralph and Helm 1993) in order to favor the next attack of the xylanasic activity and the release of reducing sugars. The cellulasic activity was quite negligible of the enzymes produced: It should be due to the "selective delignification" carried out by some kind of fungal attack that leaves the cellulose fibers almost intact (Narayanaswamy et al. 2013).

The scarce protease activity resulted surprising due to the high amount of proteins after the hydrolysis of the main polysaccharide structures.

Overall, these results on enzymatic hydrolysis revealed some information about the chemical and structural composition of hemp bran: Highly lignified, it is made of pectin that surrounds the hemicellulose-cellulose network, as in every dicotyledon plant. It also reveals the presence of starch, common in monocotyledon spp. bran and suggests the presence of protein moieties linked to cellulose fibers, the only ones which have not undergone hydrolysis.
Table 2 Enzymatic activities of the samples collected after 4, 9, 13, and 17 days of Pleurotus ostreatus SSF on hemp bran, expressed as $\mu \mathrm{mol} / \mathrm{min}$ of converted substrate. Within each enzymatical activity, means followed by the same letter did not differ significantly by $t$ test $(P$ $>0.05)$. n.d. $=$ not detected

\begin{tabular}{|c|c|c|c|c|}
\hline \multirow[t]{2}{*}{ Enzyme } & \multicolumn{4}{|c|}{ Activity ( $\mu \mathrm{mol} / \mathrm{min})$} \\
\hline & 4 days & 9 days & 13 days & 17 days \\
\hline Peroxidase & $27.58 \pm 2.08^{\mathrm{a}}$ & $51.33 \pm 1.73^{\mathrm{b}}$ & $31.82 \pm 3.11^{\mathrm{b}}$ & $53.50 \pm 3.70^{\mathrm{b}}$ \\
\hline Laccase & $3.12 \pm 0.28^{\mathrm{a}}$ & $99.01 \pm 8.49^{\mathrm{b}}$ & $74.21 \pm 7.87^{\mathrm{b}}$ & $105.27 \pm 7.66^{\mathrm{b}}$ \\
\hline Cafferoil-esterase & $2.49 \pm 0.19^{\mathrm{a}}$ & $3.55 \pm 0.78^{\mathrm{b}}$ & $3.74 \pm 0.38^{\mathrm{b}}$ & $3.06 \pm 0.32^{\mathrm{b}}$ \\
\hline Feruroil-esterase & $3.72 \pm 0.59^{\mathrm{a}}$ & $8.02 \pm 0.83^{\mathrm{b}}$ & $5.03 \pm 0.71^{\mathrm{b}}$ & $6.12 \pm 0.85^{\mathrm{b}}$ \\
\hline Xylanase & $65.77 \pm 7.63^{\mathrm{a}}$ & $456.58 \pm 14.99^{b}$ & $318.38 \pm 26.07^{\mathrm{b}}$ & $501.09 \pm 21.99^{\mathrm{b}}$ \\
\hline Pectinase & $111.08 \pm 7.68^{\mathrm{a}}$ & $258.60 \pm 6.08^{\mathrm{b}}$ & $186.70 \pm 19.43^{\mathrm{b}}$ & $325.37 \pm 16.38^{b}$ \\
\hline Amylase & $66.88 \pm 8.89^{\mathrm{a}}$ & $296.38 \pm 20.00^{\mathrm{b}}$ & $270.62 \pm 14.12^{\mathrm{b}}$ & $355.83 \pm 28.82^{b}$ \\
\hline Cellulase & $1.63 \pm 0.04^{\mathrm{a}}$ & $2.26 \pm 0.33^{\mathrm{b}}$ & $2.62 \pm 0.35^{\mathrm{b}}$ & $2.41 \pm 0.28^{\mathrm{b}}$ \\
\hline Protease & n.d. & $5.74 \pm 1.17^{\mathrm{b}}$ & $3.24 \pm 0.42^{\mathrm{a}}$ & $5.80 \pm 0.38^{\mathrm{b}}$ \\
\hline
\end{tabular}




\section{Protein Solubility and Profile of Biorefinery Products}

The yield of products obtained by the three processes was variable, depending on the process and experimental conditions (Online Resource 3). In general, Lactobacillus spp. fermentation produced the highest amount of material (around 20 g/100 g HPB for the 6-, 24-, and 72-h MR13 samples, 6- and 24-h LB32520 samples, and 6- and 24-h samples fermented by the pool of bacteria), followed by the chemical extraction procedure ( $7 \mathrm{~g} / 100 \mathrm{~g} \mathrm{HPB})$ and the $P$. ostreatus SSF process (average value of the four samples, about $1.7 \mathrm{~g} / 100 \mathrm{~g} \mathrm{HPB}$ ).

The amount of soluble proteins is reported in Fig. 2. To compare the three processes, data are expressed as mg of soluble protein/g total proteins in HPB sample. The amount obtained after protein extraction $(15.7 \mathrm{mg} / 100 \mathrm{~g} \mathrm{HPB})$ was significantly increased $(P<0.05)$ by the subsequent enzymatic treatments, with the only exception of the Flavourzyme digested sample (Fig. 2a). These results indicate that enzymes were able to solubilize proteins from the extracts. Protein solubility is a function of hydrophilicity and electrostatic repulsions which are generally increased after cleavage of peptide bonds, due to the higher number of ionizable amino and carboxyl groups (Lamsal et al. 2007). Pepsin treatment was particularly efficient, leading to the solubilization of about $10 \%$ (107.64 mg/g HPB protein) of the initial HPB proteins. The release of soluble proteins by microbial fermentation was dependent on Lactobacillus spp. strain and incubation time. The maximum amount was observed after $6 / 24 \mathrm{~h}$ for $\mathrm{C} 1112(18.36$ and $19.06 \mathrm{mg} / \mathrm{g}$ HPB protein), after $6 \mathrm{~h}$ for MR13 $(35.24 \mathrm{mg} / \mathrm{g}$ HPB protein), and after $24 \mathrm{~h}$ for strain LB325 $(38.48 \mathrm{mg} / \mathrm{g}$ HPB protein), with the solubilization of $1.83,3.52$, and $3.84 \%$ of the initial HPB proteins, respectively. As the substrate was sterilized before incubation, the increase in soluble proteins can be assigned to the hydrolysis of substrate proteins by bacterial proteases. Similarly, fermentation of sorghum, green gram, and their composite meal for $24 \mathrm{~h}$ increased the soluble protein from 5.1 to $6.2 \%$ while prolonged fermentation beyond $24 \mathrm{~h}$ did not cause any further increase in soluble proteins (Chavan et al. 1988). In a previous research, pea seeds were fermented by L. plantarum $299 \mathrm{v}$ in monoculture under different time ( 3 h, 3 , and 7 days) and temperature (22,30, and $37^{\circ} \mathrm{C}$ ) conditions. Results showed an initial slight increase in soluble proteins in the first $3 \mathrm{~h}$, a decrease in the subsequent 3 days, and again an increase that led to the highest content after 7 days fermentation at $30^{\circ} \mathrm{C}$, suggesting that peptide hydrolysis occurred mainly through secondary fermentation (Jakubczyk et al. 2013). SSF of HBP by P. ostreatus was effective in releasing proteins starting from 9 days of incubation, when about $2 \%$ of HBP proteins were solubilized (18.63 $\mathrm{mg} / \mathrm{g}$ HPB protein). The effect of SSF by $P$. ostreatus was previously evaluated on kidney beans and oats, leading to an increase of soluble proteins of $13 \%$ and $6 \%$, respectively (Espinosa-Paez et al. 2017). Other reports showed the effect of SSF by Aspergillus oryzae and Rhizopus spp. on defatted rice bran and wheat bran. Rhizopus spp. significantly increased protein solubility after $48 \mathrm{~h}$ of fermentation, while the effect of $A$. oryzae fermentation was observed only after $72 \mathrm{~h}$ (Moreira da Silveira and Badiale-Furlong 2009).

The profile of soluble proteins was achieved through SDSPAGE (Fig. 3). The hydrolysis pattern was observably different. Degradation of HPBPI proteins (ranging from around 50 to $10 \mathrm{kDa}$ ) to smaller peptides was observed after any enzyme treatment. Pepsin, Flavourzyme, Alcalase, and Protamex showed the highest degree of hydrolysis with only a smeared band of MW around $10 \mathrm{kDa}$. Trypsin and chymotrypsin hydrolysates showed bands between 10 and $15 \mathrm{kDa}$, while those of pancreatin and Neutrase showed higher MW proteins in the range of 20-50 kDa, indicating a lower proteolytic activity. Lactobacillus spp. fermented samples showed the presence of a main smeared band at around $10 \mathrm{kDa}$, and two minor bands at 20 and $25 \mathrm{kDa}$. The intensity of the minor band decreased after 24 and $72 \mathrm{~h}$, with strains $\mathrm{C} 1112$ and MR13,
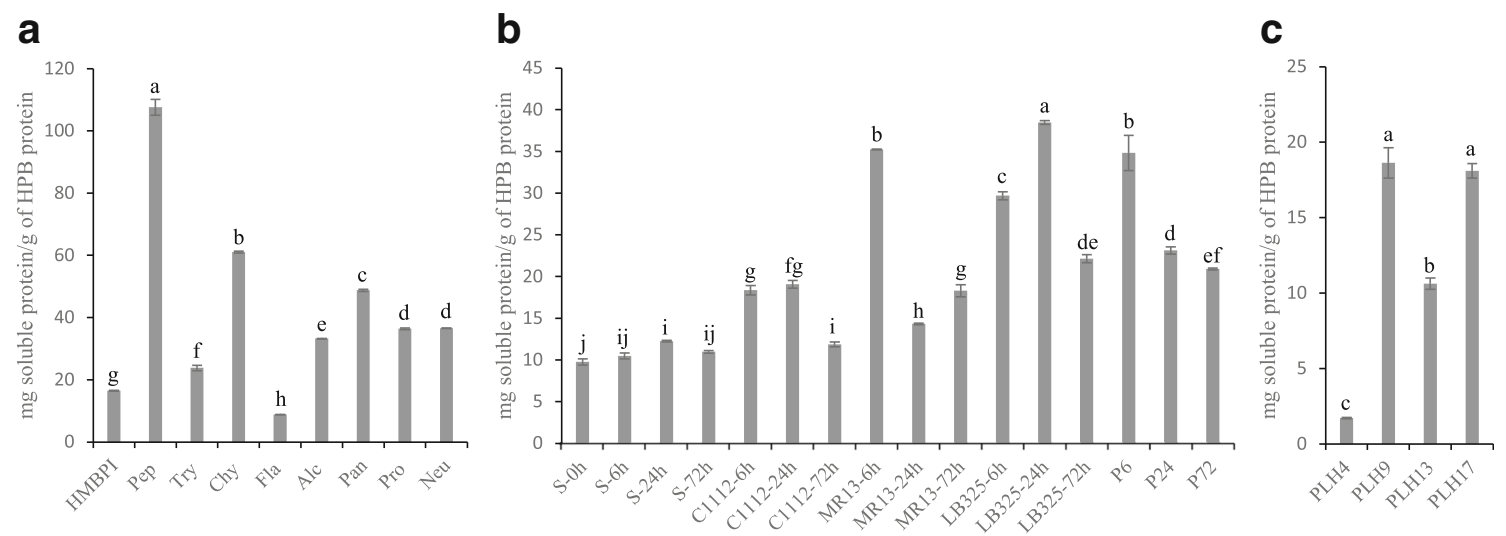

Fig. 2 Soluble protein content (mg soluble protein/g of HPB total proteins) of products obtained after biorefinery processes of HPB. a Enzymatic hydrolysis. b Fermentation by Lactobacillus spp. (LB325, C1112, MR13, and their pool, at different incubation times). c SSF by
Pleurotus ostreatus (samples PLH after 4, 9, 13, and 17 days of incubation). ${ }^{\mathrm{a}-\mathrm{j}}$ Means followed by the same letter in each plot did not differ significantly (Tukey test, $P<0.05$ ) 
Fig. 3 SDS-PAGE of products obtained after biorefinery processes of HPB. a Enzymatic hydrolysis. b Fermentation by Lactobacillus spp. (LB325, C1112, MR13, and their pool, P, at different incubation times). c SSF by Pleurotus ostreatus (sample PLH after 4, 9, 13, and 17 days of incubation)

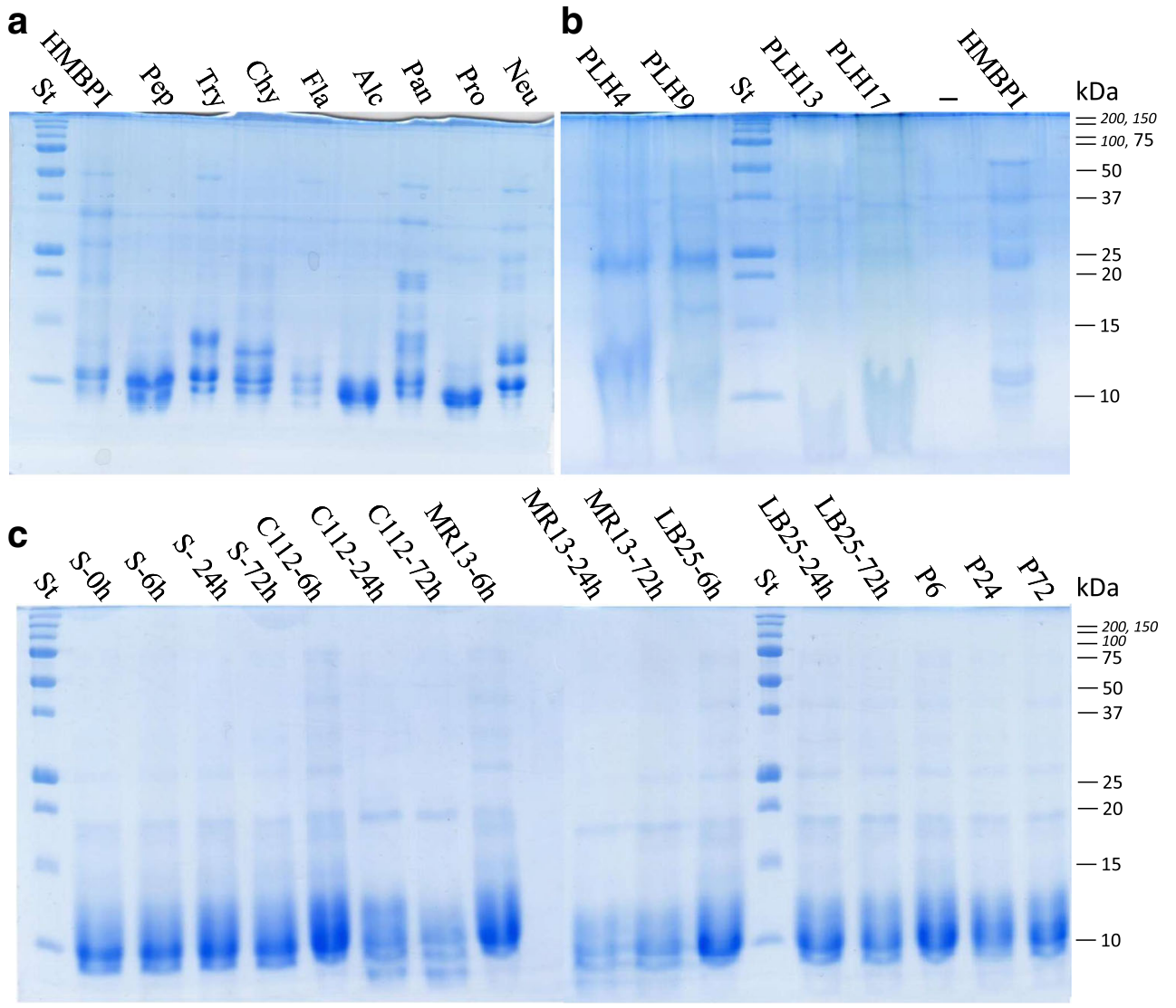

suggesting a degradation to smaller peptides, not detectable by this technique. Finally, the 4 days SSF sample showed the presence of one main band of MW between 20 and $25 \mathrm{kDa}$ and a smear between 10 and $15 \mathrm{kDa}$. The latter after 9 days started to decrease to lower MW and the 20-25 kDa band completely disappeared after 13-day incubation. These results are in line with the protease activity measured in SSF samples, which started after 4 days of incubation.

The above results indicated that the three processes were able to partially solubilize HPB proteins and hydrolyze them to proteins/peptides with MW around and below $15 \mathrm{kDa}$. The more effective treatment was pepsin hydrolysis of HPBPI (yield of soluble proteins of about 10\%), followed by the 24 h fermentation by LB325 (about 4\%) and the P. ostreatus SSF after 9 days of treatment (2\%).

\section{Antioxidant Capacity of Biorefinery Products}

The in vitro antioxidant capacities of biorefinery products were evaluated by ABTS, $\mathrm{Fe}^{2+}$ chelating, and FRAP assays (Fig. 4). The first method exploits the scavenging capacity of hydrogendonating antioxidants toward the free radical $\mathrm{ABTS}^{+}$. The second one measures the ability of antioxidants to chelate transition metal ions like $\mathrm{Fe}^{2+}$, while the third is used to evaluate the ability of natural antioxidants to donate electrons, reducing reactive radical species. To make a comparison between the products obtained by the different processes, results are referred to the amount of lyophilized powder obtained by each of them.

Protein hydrolysates of HPB (Fig. 4a) had similar ABTS and FRAP profiles, showing a general increase of activity after enzymatic treatment, with respect to the initial extract. For both assays, chymotrypsin hydrolysate had the best activity, respectively about 7 times and 10 times higher than HPBPI. $\mathrm{Fe}^{2+}$ chelating assay showed a completely different trend, with only a slight increase of activity observed, again, after chymotrypsin treatment. Lactobacillus spp. hydrolyzed samples (Fig. 4b) showed only slight increase of ABTS and FRAP values after fermentation, with the highest activity (about 1.3 times than control) measured after 72-h incubation with the pool of Lactobacillus spp. strains. More relevant variations were observed for $\mathrm{Fe}^{2+}$ chelating activity which increased of about 1.8 times after 6-h incubation with LB325 and with the pool of bacteria. The antioxidant activity of SSF products (Fig. 4c) changed depending on the treatment time. ABTS and FRAP trends were similar with the highest activity after 9 days of treatment, while the highest $\mathrm{Fe}^{2+}$ chelating activity was observed after 13 days.

Comparing the activities of products obtained by different processes, it is possible to note that chymotrypsin hydrolysate had ABTS activity value similar to the sample derived from 9 days of SSF by P. ostreatus (respectively 7.0 and $8.0 \mathrm{mg}$ AA $\mathrm{eq} / \mathrm{g}$ ), while bacterial fermented products had in general lower activity (with a maximum of $3.8 \mathrm{mg} \mathrm{AA} \mathrm{eq} / \mathrm{g}$, observed for the 
a
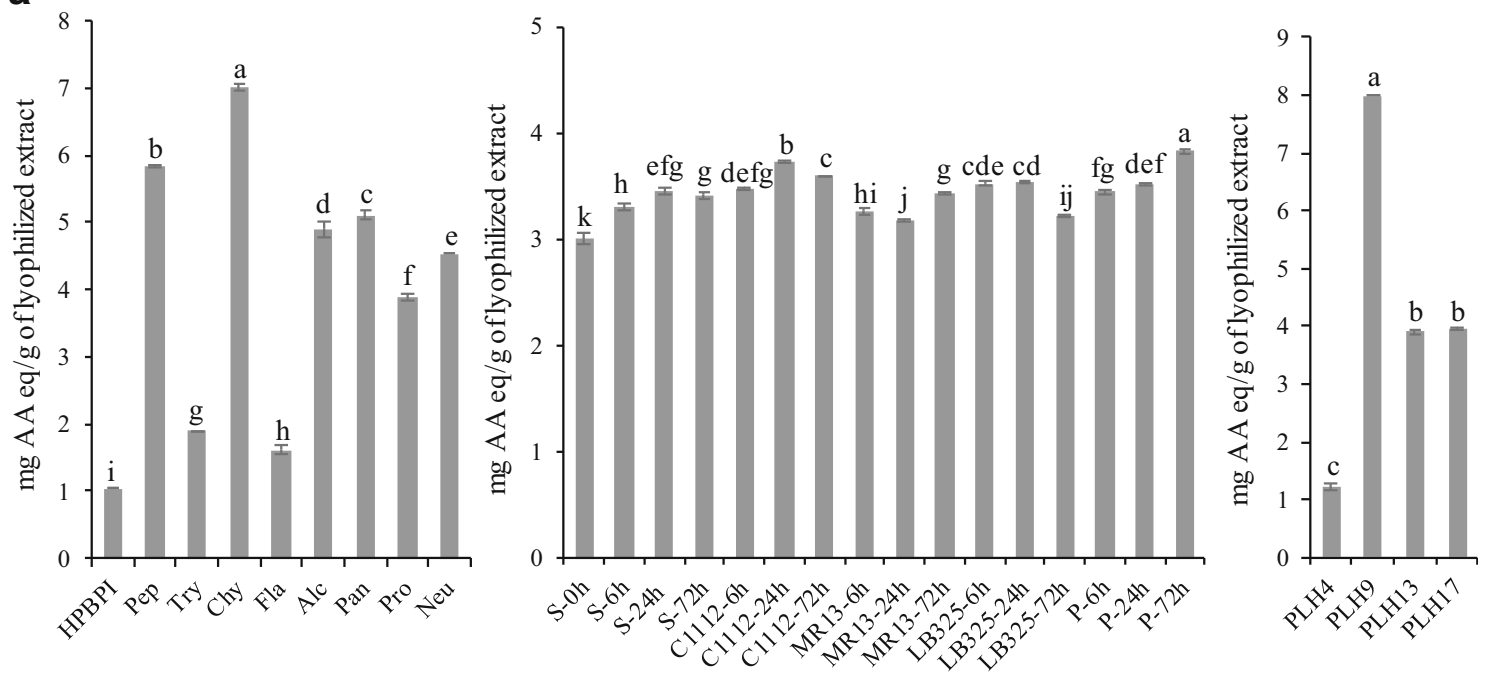

b
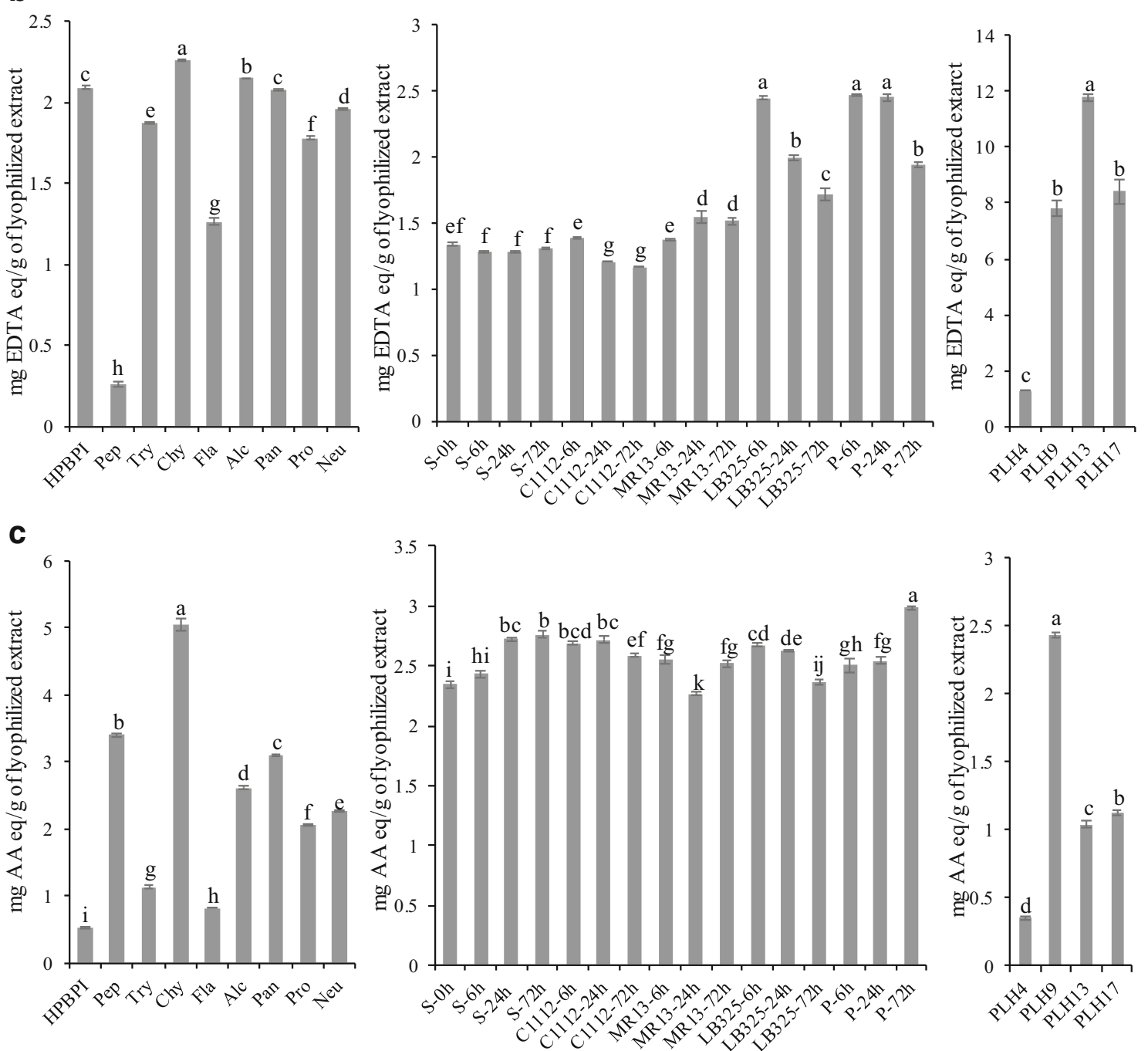

Fig. 4 Antioxidant activity of products obtained after biorefinery processes of HPB by enzymatic hydrolysis, fermentation by Lactobacillus spp. (LB325, C1112, MR13, and their pool, at different incubation times), and SSF by Pleurotus ostreatus (sample PLH after 4, 9,13 , and 17 days of incubation), evaluated by different assays. a ABTS (mg AA eq/g of lyophilized extract). $\mathbf{b} \mathrm{Fe}^{2+}$ chelating activity (mg EDTA eq/g of lyophilized extract). c FRAP (mg AA eq/g of lyophilized extract). ${ }^{\mathrm{a}-\mathrm{k}}$ Means followed by the same letter in each plot did not differ significantly (Tukey test, $P<0.05$ ) 
72-h sample fermented by the pool of bacteria). $\mathrm{Fe}^{2+}$ chelating activity was particularly high in the 13 days $P$. ostreatus fermented sample (11.8 $\mathrm{mg}$ EDTA eq/g), about 6 times the best activities measured in enzymatic and microbial samples (2.2 mg EDTA eq/g for chymotrypsin hydrolysate and $2.5 \mathrm{mg}$ EDTA eq/g for 6-h samples fermented with LB325 and the pool of bacteria). Finally, the highest FRAP values were obtained for chymotrypsin hydrolysate $(5.0 \mathrm{mg}$ EDTA eq $/ \mathrm{g}$ ) with respect to Lactobacillus spp. strains and P. ostreatus samples (highest values of 3.0 and $2.4 \mathrm{mg}$ EDTA eq/g for the 72-h bacterial pool fermented sample and the 9 days $P$. ostreatus treated sample, respectively). The above results indicated that all the three processes were able to convert HPB into products with antioxidant properties, though the mechanisms responsible of the observed activities cannot be defined at this stage of research. Antioxidant properties have been previously reported for hemp seed protein hydrolysates obtained by enzymatic treatment of protein extracts (Tang et al. 2009; Girgih et al. 2013; Wang and Xiong 2019). On a similar experiment conducted on rapeseed protein hydrolysates, the EC50 was $0.71 \mathrm{mg} / \mathrm{mL}$, similar to what we found in HPB prior microbial hydrolysis (Pan et al. 2011). Despite a comparison of data cannot be made, due to differences in experimental conditions, a variability in the antioxidant activity dependent on the type of protease, as observed in the present work, was reported for hemp seed protein isolate treated by six different proteases (Tang et al. 2009). A simulated gastrointestinal digest of hemp seed protein isolate improved some of its antioxidant activities (DPPH and hydroxyl and superoxide radical scavenging), while the crude protein extract and some peptide fractions showed significantly stronger metal reducing and chelating activities (Girgih et al. 2013). Products with antioxidant properties obtained by bacterial or fungal fermentation of hemp seeds have not been previously reported, but many examples are reported in the literature for other substrates. Flours from different cereals, pseudo-cereals, and legumes showed antioxidant properties after fermentation with lactic acid bacteria, and activity was dependent on peptides sharing compositional features typical of other antioxidant peptides (Rizzello et al. 2016). SSF by Rhizopus oryzae RCK2012 was an efficient method for the improvement of antioxidant potential (DPPH and ABTS radical scavenging) of cereals, caused by the release of soluble bioactive compounds. Among them are phenolic compounds and some other water-soluble compounds such as bioactive small peptides and oligosaccharides (Bhanja Dei and Kuhad 2014). Recently, the enhancement of antioxidant activity of fermented okara was obtained by SSF with Rhizopus oligosporus and Aspergillus oryzae. The release of isoflavone-derived compounds and small molecular weight peptides and amino acids, produced during the fermentation process, was considered to play role for the enhanced activities obtained using both fungi (Sitanggang et al. 2019).

\section{ACE-Inhibitory Activity of Biorefinery Products}

The antihypertensive properties of biorefinery products were measured by an in vitro assay testing the ability to inhibit angiotensin-converting enzymes. Results are expressed as $\mathrm{IC}_{50}$ values, i.e. the concentration of samples (in $\mathrm{mg}$ of lyophilized powder/L), able to induce a $50 \%$ inhibition of the enzyme (Table 3 ).

A strong variability in the activity was observed among the samples. Enzymatic hydrolysis with different proteolytic enzymes generally released ACE-inhibitory peptides from HPBPI. Indeed, the $\mathrm{IC}_{50}$ value of the latter (about $4268 \mathrm{mg} /$ L) decreased over 35 times in pepsin hydrolysate (about 120 $\mathrm{mg} / \mathrm{L}$ ), over 25 times in Neutrase and Alcalase hydrolysates (respectively 155 and $176 \mathrm{mg} / \mathrm{L}$ ) and, to a lesser extent, in all the other hydrolysates. Many other studies have demonstrated that antihypertensive peptides with varying potencies can be generated simply by treating protein substrates with different enzymes and enzyme: substrate ratios (Rizzello et al. 2016; Malomo et al. 2015). The differences in the activities are dependent on the different peptide patterns generated by enzymes. It is well known that ACE interaction with substrate or inhibitors is related to the presence of hydrophobic amino acids, to the size of the peptides and to the specific location of amino acids in peptide chain (Mundi and Aluko 2014). Lactobacillus spp. fermentation also led to a decrease of $\mathrm{IC}_{50}$ values with respect to the initial sample (S-0 h, 4298 $\mathrm{mg} / \mathrm{L}$ ). The lowest values, indicating highest antihypertensive activity, were measured after 24 and $72 \mathrm{~h}$ of fermentation with C1112 strain (837 and $720 \mathrm{mg} / \mathrm{L}$, respectively). For the other Lactobacillus spp. fermented samples (with exception of LB325 after $72 \mathrm{~h}$ ), $\mathrm{IC}_{50}$ ranged from around 1000 to 1300 $\mathrm{mg} / \mathrm{L}$. According to previous research on wholemeal wheat and pea, Lactobacillus spp. were able to release peptides with antihypertensive effects depending on the strain and incubation time (Rizzello et al. 2016). All the samples obtained by SSF with $P$. ostreatus had ACE-inhibitory activity. The $\mathrm{IC}_{50}$ values decreased from $1160 \mathrm{mg} / \mathrm{L}$ after 4 days of incubation to 738,877 , and $601 \mathrm{mg} / \mathrm{L}$ after 9,13 , and 17 days, respectively. As a protease activity was starting to be detected in the 9 days sample, it is possible that the antihypertensive activity, which significantly increased after that time, could be related to the release of bioactive peptides from substrate proteins. The results of ACE-inhibitory assay indicated that the three biorefinery processes were able to convert HPB into antihypertensive products. The highest activities measured in samples that underwent the Lactobacillus spp. and the P. ostreatus processes were similar, and 6 and 5 times lower than the best activity measured in enzymatic-treated samples. These values are in the range of previous results obtained on hemp seed protein hydrolysates. In particular, a pepsin-pancreatin digest of hemp seed protein isolate produced hydrolysates with ACE-inhibitory activity and $\mathrm{IC}_{50}$ value of $670 \mathrm{mg} / \mathrm{L}$ (Girgih 
Table 3 ACE-inhibitory activity expressed as $\mathrm{IC}_{50}$ values $(\mathrm{mg} / \mathrm{L})$, of products obtained after biorefinery processes of HPB by (A) enzymatic hydrolysis; (B) fermentation by Lactobacillus spp. (LB325, C1112, MR13, and their pool); and (C) SSF by Pleurotus ostreatus. Means with different letters are statistically significant by post hoc Tukey test $(P<0.05)$

\begin{tabular}{ll}
\hline Process and samples & ACE-inhibitory $\left(\mathrm{IC}_{50} \mathrm{mg} / \mathrm{L}\right)$ \\
\hline Enzymatic hydrolysis & \\
HMBPI & $4268.00 \pm 1.02^{\mathrm{a}}$ \\
Pepsin & $120.30 \pm 1.85^{\mathrm{i}}$ \\
Trypsin & $2145.00 \pm 1.03^{\mathrm{b}}$ \\
Chymotrypsin & $290.80 \pm 1.08^{\mathrm{f}}$ \\
Flavourzyme & $1440.00 \pm 1.04^{\mathrm{c}}$ \\
Alcalase & $176.00 \pm 1.06^{\mathrm{g}}$ \\
Pancreatin & $849.70 \pm 1.05^{\mathrm{d}}$ \\
Protamex & $329.60 \pm 1.02^{\mathrm{e}}$ \\
Neutrase & $155.80 \pm 1.05^{\mathrm{h}}$ \\
Bacterial fermentation & \\
Control after $0 \mathrm{~h}$ & $4298.00 \pm 1.01^{\mathrm{b}}$ \\
Control after $6 \mathrm{~h}$ & $4384.00 \pm 1.06^{\mathrm{a}}$ \\
Control after $24 \mathrm{~h}$ & $2079.00 \pm 1.04^{\mathrm{d}}$ \\
Control after $72 \mathrm{~h}$ & $2211.00 \pm 1.09^{\mathrm{c}}$ \\
C1112 after $6 \mathrm{~h}$ & $1287.00 \pm 1.01^{\mathrm{f}}$ \\
C1112 after $24 \mathrm{~h}$ & $836.70 \pm 1.05^{\circ}$ \\
C1112 after $72 \mathrm{~h}$ & $719.50 \pm 1.08^{\mathrm{p}}$ \\
MR13 after $6 \mathrm{~h}$ & $1233.00 \pm 1.02^{\mathrm{h}}$ \\
MR13 after $24 \mathrm{~h}$ & $1101.00 \pm 1.05^{\mathrm{m}}$ \\
MR13 after $72 \mathrm{~h}$ & $1010.00 \pm 1.05^{\mathrm{n}}$ \\
LB325 after $6 \mathrm{~h}$ & $1184.00 \pm 1.03^{\mathrm{k}}$ \\
LB325 after $24 \mathrm{~h}$ & $1202.00 \pm 1.03^{\mathrm{j}}$ \\
LB325 after $72 \mathrm{~h}$ & $1836.00 \pm 1.06^{\mathrm{e}}$ \\
Pool after $6 \mathrm{~h}$ & $1249.00 \pm 1.01^{\mathrm{g}}$ \\
Pool after $24 \mathrm{~h}$ & $1224.00 \pm 1.02^{\mathrm{i}}$ \\
Pool after $72 \mathrm{~h}$ & $1147.00 \pm 1.00^{1}$ \\
\hline Polid-state fermentation & \\
\hline
\end{tabular}

et al. 2011). Besides, $\mathrm{IC}_{50}$ values from 16 to $228 \mathrm{mg} / \mathrm{L}$ were measured in hemp seed proteins treated by different enzymes (Malomo et al. 2015). Thus, HPB can be a source of antihypertensive compounds with comparable activity to that obtained from the entire hemp seed. Interestingly, fractionation of hemp hydrolysates did not improve activity and isolated peptides responsible for antihypertensive activity had similar $\mathrm{IC}_{50}$ values (17 mg/L for WVYY and $269 \mathrm{mg} / \mathrm{L}$ for WYT, Girgih et al. 2014b). These data suggest the potential direct use of these hydrolysates, without further fractionation or purification steps, which are normally required to enhance potency, but increase the cost of the process. Another work has shown that when hemp seed and hemp meal hydrolysates obtained by simulated gastrointestinal digestion were administered in the diet of spontaneously hypertensive rats, it had strong hypotensive effects (Girgih et al. 2014a). Despite the antihypertensive activity in vivo of the biorefinery products from HPB has still to be verified, the preliminary results of the in vitro assays are encouraging starting points for an industrial exploitation as ingredients for functional foods, nutraceuticals, or pharmaceutical formulation for the prevention and treatment of hypertension.

\section{Conclusions}

The development of sustainable solutions to recover potentially valuable food byproducts and waste is one of the main challenges of our society. In the present work, three different biorefinery processes for recovering bioactive compounds from protein-containing HPB were assessed and compared. The chemical procedure consisted of an alkaline protein extraction followed by hydrolysis by one of the eight different proteolytic enzymes. The microbial liquid fermentation was performed using different Lactobacillus spp., while $P$. ostreatus was assessed in a solid-state biorefinery system. The resulting products exhibited different levels of antioxidant (including ABTS radical scavenging, $\mathrm{Fe}^{2+}$ chelating capacity, and ferric reducing power) and antihypertensive activity (evaluated by in vitro assays). The antihypertensive activity was particularly noteworthy, as the $\mathrm{IC}_{50}$ values of $\mathrm{ACE}$ inhibition were comparable to values in protein hydrolysates from the whole seed. These results indicate that bioactivity is not impaired by industrial processing, and further, these compounds remain in the generated byproducts. Pepsin treatment was the most promising biorefinery process in terms of ACE inhibition. A weaker effect, but still significant, was observed for samples from Lactobacillus spp. fermentation (L. rhamnosus C1112 was the most active) and SSF by $P$. ostreatus (albeit after 9 days of incubation). These results suggest that HPB could be transformed into value-added products that would increase the hemp seed market in the food, cosmetic, and pharmaceutical sectors. Product yield and bioactivity could be further increased by process combination and scale-up optimization.

Supplementary Information The online version contains supplementary material available at https://doi.org/10.1007/s11947-020-02550-6.

Authors' Contributions Leonardo Setti: conceptualization, data curation, funding acquisition, methodology, project administration, resources, supervision, validation, visualization, writing — original draft, and writing - review and editing. 
Seyedeh Parya Samaei: data curation, formal analysis, investigation, methodology, software, visualization, writing - original draft, and writing - review and editing.

Irene Maggiore: data curation, formal analysis, investigation, visualization, writing - original draft, and writing - review and editing.

Lorenzo Nissen: conceptualization, data curation, formal analysis, investigation, methodology, software, supervision, visualization, writing original draft, and writing - review and editing.

Andrea Gianotti: conceptualization, data curation, funding acquisition, methodology, project administration, resources, supervision, validation, visualization, writing - original draft, and writing - review and editing.

Elena Babini: conceptualization, data curation, funding acquisition, methodology, project administration, resources, supervision, validation, visualization, writing — original draft, and writing — review and editing.

Funding This research was supported by Alma IDEA grant from University of Bologna. Open access funding provided by Alma Mater Studiorum - Università di Bologna within the CRUI-CARE Agreement.

\section{Compliance with Ethical Standards}

Competing Interests The authors declare that they have no competing interests.

Ethics Approval Not applicable.

Supplementary Information The online version contains supplementary material available at https://doi.org/10.1007/s11947-020-02550-6.

Open Access This article is licensed under a Creative Commons Attribution 4.0 International License, which permits use, sharing, adaptation, distribution and reproduction in any medium or format, as long as you give appropriate credit to the original author(s) and the source, provide a link to the Creative Commons licence, and indicate if changes were made. The images or other third party material in this article are included in the article's Creative Commons licence, unless indicated otherwise in a credit line to the material. If material is not included in the article's Creative Commons licence and your intended use is not permitted by statutory regulation or exceeds the permitted use, you will need to obtain permission directly from the copyright holder. To view a copy of this licence, visit http://creativecommons.org/licenses/by/4.0/.

\section{References}

Abdel-Hamid, A. M., Solbiati, J. O., \& Cann, I. K. (2013). Insights into lignin degradation and its potential industrial applications. Advances in Applied Microbiology, 82, 1-28.

Ajila, C. M., Gassara, F., Brar, S. K., et al. (2012). Polyphenolic antioxidant mobilization in apple pomace by different methods of solidstate fermentation and evaluation of its antioxidant activity. Food and Bioprocess Technology, 5, 2697-2707.

Akpinar, M., \& Urek, R. O. (2012). Production of ligninolytic enzymes by solid-state fermentation using Pleurotus eryngii. Preparative Biochemistry \& Biotechnology, 42(6), 582-597.

Babini, E., Tagliazucchi, D., Martini, S., Dei Piu, L., \& Gianotti, A. (2017). LC-ESI-QTOF-MS identification of novel antioxidant peptides obtained by enzymatic and microbial hydrolysis of vegetable proteins. Food Chemistry, 228, 186-196.
Babini, E., Taneyo-Saa, D. L., Tassoni, A., Ferri, M., Kraft, A., GränHeedfeld, J., Bretz, K., Roda, A., Michelini, E., Calabretta, M. M., Guillon, F., Tagliazucchi, D., Martini, S., Nissen, L., \& Gianotti, A. (2020). Microbial fermentation of industrial rice-starch byproduct as valuable source of peptide fractions with health-related activity. Microorganisms, 8, 1-16.

Baiano, A. (2014). Recovery of biomolecules from food wastes-a review. Molecules, 19(9), 14821-14842.

Bailey, M. J., Biely, P., \& Poutanen, K. (1992). Interlaboratory testing of methods for assay of xylanase activity. Journal of Biotechnology, 23, 257-270.

Bao, L., Li, Y., Wang, Q., Han, J., Yang, X., Li, H., Wang, S., Wen, H., Li, S., \& Liu, H. (2013). Nutritive and bioactive components in rice fermented with the edible mushroom Pleurotus eryngii. Mycology, 4, 96-102.

Benzie, I. F. F., \& Strain, J. J. (1996). The ferric reducing ability of plasma as a measure of antioxidant power: the FRAP assay. Analytical Biochemistry, 239, 70-76.

Bhanja Dei, T., \& Kuhad, R. C. (2014). Upgrading the antioxidant potential of cereals by their fungal fermentation under solid-state cultivation conditions. Letters in Applied Microbiology, 59, 493-499.

Castillo, M., Martin-Orue, S. M., Manzanilla, E. G., Badiola, I., Martin, M., \& Gasa, M. J. (2006). Quantification of total bacteria, enterobacteria and lactobacilli populations in pig digesta by realtime PCR. Veterinary Microbiology, 114, 165-170.

Chavan, U. D., Chavan, J. K., \& Kadam, S. S. (1988). Effect of fermentation on soluble proteins and in vitro protein digestibility of sorghum, green gram and sorghum green gram blends. Journal of Food Science, 53, 1574-1575.

Dashtban, M., Schraft, H., Syed, T. A., \& Qin, W. (2010). Fungal biodegradation and enzymatic modification of lignin. International Journal of Biochemistry and Molecular Biology, 1, 36-50.

Di Mattia, C., Martuscelli, M., Sacchetti, G., et al. (2013). Effect of fermentation and drying on procyanidins, antiradical activity and reducing properties of cocoa beans. Food Bioprocess and Technology, 6, 3420-3432.

Espinosa-Paez, E., Alanis-Guzman, M. G., Hernandez-Luna, C. E., BaezGonzalez, J. G., Amaya-Guerra, J. G., Amaya-Guerra, C. A., \& Andres-Grau, A. M. (2017). Increasing antioxidant activity and protein digestibility in Phaseolus vulgaris and Avena sativa by fermentation with the Pleurotus ostreatus fungus. Molecules, 22, 2275. https://doi.org/10.3390/molecules22122275.

Fernández-Fueyo, E., Castanera, R., Ruiz-Dueñas, F. J., López-Lucendo, M. F., Ramírez, L., Pisabarro, A. G., \& Martinez, A. T. (2014). Ligninolytic peroxidase gene expression by Pleurotus ostreatus: differential regulation in lignocellulose medium and effect of temperature and pH. Fungal Genetics and Biology, 72, 150-161.

Fonteles, T. V., Costa, M. G. M., de Jesus, A. L. T., et al. (2012). Optimization of the fermentation of cantaloupe juice by Lactobacillus casei NRRL B-442. Food and Bioprocess Technology, 5, 2819-2826.

Garcia-Amezquita, L. E., Tejada-Ortigoza, V., Serna-Saldivar, S. O., et al. (2018). Dietary fiber concentrates from fruit and vegetable by-products: processing, modification, and application as functional ingredients. Food and Bioprocess Technology, 11, 1439-1463.

Girgih, A. T., Udenigwe, C. C., Adebiyi, A. P., \& Aluko, R. E. (2011). Kinetics of enzyme inhibition and antihypertensive effects of hemp seed (Cannabis sativa L.) protein hydrolysates. Journal of the American Oil Chemists' Society, 88(11), 1767-1774.

Girgih, A. T., Udenigwe, C. C., \& Aluko, R. E. (2013). Reverse-phase HPLC separation of hemp seed (Cannabis sativa L.) protein hydrolysate produced peptide fractions with enhanced antioxidant capacity. Plant Foods for Human Nutrition, 68, 39-46.

Girgih, A. T., Alashi, A., He, R., Malomo, S. A., \& Aluko, R. E. (2014a). Preventive and treatment effects of a hemp seed (Cannabis sativa L.) meal protein hydrolysate against high blood pressure in 
spontaneously hypertensive rats. European Journal of Nutrition, 53(5), 1237-1246.

Girgih, A. T., He, R., \& Aluko, R. E. (2014b). Kinetics and molecular docking studies of the inhibitions of angiotensin converting enzyme and renin activities by hemp seed (Cannabis sativa L.) peptides. Journal of Agricultural and Food Chemistry, 62(18), 4135-4144.

Giuliani, S., Piana, C., Setti, L., Hochkoeppler, A., Pifferi, P. G., Williamson, G., \& Faulds, C. B. (2001). Synthesis of pentylferulate by a feruloyl esterase from Aspergillus niger using water-in-oil microemulsions. Biotechnology Letters, 23, 325-330.

Hafeez, Z., Cakir-Kiefer, C., Roux, E., Perrin, C., Miclo, L., \& DaryMourot, A. (2014). Strategies of producing bioactive peptides from milk proteins to functionalize fermented milk products. Food Research International, 63, 71-80.

Hatfield, R. D. (1993). Cell wall polysaccharide interactions and degradability. In H. G. Jung, D. R. Buxton, R. D. Hatfield, \& J. Ralph (Eds.), Forage cell wall structure and digestibility (pp. 285-313). Madison: American Society of Agronomy, Inc., Crop Science Society of America, Inc., Soil Science Society of America, Inc..

Jakubczyk, A., Karas, M., Baraniak, B., \& Pietrzak, M. (2013). The impact of fermentation and in vitro digestion on formation angiotensin converting enzyme (ACE) inhibitory peptides from pea proteins. Food Chemistry, 141, 3774-3780.

Kunitz, M. (1947). Crystalline soybean trypsin inhibitor. The Journal of General Physiology, 30, 291-310.

Lamsal, B. P., Jung, S., \& Johnson, L. A. (2007). Rheological properties of soy protein hydrolysates obtained from limited enzymatic hydrolysis. LWT - Food Science and Technology, 40(7), 1215-1223.

Latimer, G. W. (2016). Official methods of analysis of AOAC International. Gaithersburg: AOAC International.

Malomo, S. A., He, R., \& Aluko, R. E. (2014). Structural and functional properties of hemp seed protein products. Journal of Food Science, 79(8), C1512-C1521.

Malomo, S. A., Onuh, J. O., Girgih, A. T., \& Aluko, R. E. (2015). Structural and antihypertensive properties of enzymatic hemp seed protein hydrolysates. Nutrients, 7(9), 7616-7632.

Martínez-Alvarez, O., Chamorro, S., \& Brenes, A. (2015). Protein hydrolysates from animal processing by-products as a source of bioactive molecules with interest in animal feeding: a review. Food Research International, 73, 204-212.

Masutti, D. C., Borgognone, A., \& Setti, L. (2012). Production of enzymes from rice husks and wheat straw in solid state fermentation. Chemical Engineering Transactions, 27, 133-138.

Masutti, D. C., Borgognone, A., Scardovi, F., Vaccari, C., \& Setti, L. (2015). Effects on the enzymes production from different mixes of agro-food wastes. Chemical Engineering Transactions, 43, 487492.

Moreira da Silveira, C., \& Badiale-Furlong, E. (2009). Sperathe effects of solid-state fermentation in the functional properties of defatted rice bran and wheat bran. Brazilian archives of biology and technology, 52(6), 1555-1562.

Mundi, S., \& Aluko, R. E. (2014). Inhibitory properties of kidney bean protein hydrolysate and its membrane fractions against renin, angiotensin converting enzyme, and free radicals. Austin journal of nutrition and food sciences, 2, 1008-1019.

Murthy, P. S., \& Naidu, M. M. (2012). Production and application of xylanase from Penicillium sp. utilizing coffee by-products. Food and Bioprocess Technology, 5, 657-664.

Narayanaswamy, N., Dheeran, P., Verma, S., \& Kumar, S. (2013). Biological pretreatment of lignocellulosic biomass for enzymatic saccharification. In Z. Fang (Ed.), Pretreatment techniques for biofuels and biorefineries. Green Energy (pp. 3-34). Berlin: Springer.

Nath, A., Verasztó, B., Basak, S., et al. (2016). Synthesis of lactosederived nutraceuticals from dairy waste whey-a review. Food and Bioprocess Technology, 9, 16-48.
Nissen, L., Demircan, B., Taneyo-Saa, D. L., \& Gianotti, A. (2019). Shift of aromatic profile in probiotic hemp drink formulations: a metabolomic approach. Microorganisms, 7, 1-18.

Nissen, L., di Carlo, E., \& Gianotti, A. (2020a). Prebiotic potential of hemp blended drinks fermented by probiotics. Food Research International, 131, 109029. https://doi.org/10.1016/j.foodres.2020. 109029.

Nissen, L., Bordoni, A., \& Gianotti, A. (2020b). Shift of volatile organic compounds (VOCs) in gluten-free hemp-enriched sourdough bread: a metabolomic approach. Nutrients, 12, 1050. https://doi.org/10. 3390/nu12041050.

Nwamaioha, N., \& Ibrahim, S. A. (2017). A selective medium for the enumeration and differentiation of Lactobacillus delbrueckii ssp. bulgaricus. Journal of Dairy Science, 101, 4953-4961.

Oberoi, H. S., Chavan, Y., Bansal, S., et al. (2010). Production of cellulases through solid state fermentation using kinnow pulp as a major substrate. Food and Bioprocess Technology, 3, 528-536.

Pan, M., Jiang, T. S., \& Pan, J. L. (2011). Antioxidant activities of rapeseed protein hydrolysates. Food and Bioprocess Technology, 4, 1144-1152.

Peanparkdee, M., Iwamoto, S., \& Yamauchi, R. (2017). Preparation and release behavior of gelatin-based capsules of antioxidants from ethanolic extracts of Thai riceberry bran. Food and Bioprocess Technology, 10, 1737-1748.

Pojić, M., Mišan, A., Sakač, M., Dapčević Hadnađev, T., Šarić, B., Milovanović, I., \& Hadnađev, M. (2014). Characterization of byproducts originating from hemp oil processing. Journal of Agricultural and Food Chemistry, 62(51), 12436-12442.

Ralph, J., \& Helm, R. F. (1993). Lignin/hydroxycinnamic acid/polysaccharide complexes: synthetic models for regiochemical characterization. In H. G. Jung, D. R. Buxton, R. D. Hatfield, \& J. Ralph (Eds.), Forage cell wall structure and digestibility (pp. 201246). Madison: ASA-CSSA-SSSA.

Raveschot, C., Cudennec, B., Coutte, F., Flahaut, C., Fremont, M., Drider, D., \& Dhulster, P. (2018). Production of bioactive peptides by Lactobacillus species: from gene to application. Frontiers in Microbiology, 9, 2354. https://doi.org/10.3389/fmicb.2018.02354.

Re, R., Pellegrini, N., Proteggente, A., Pannala, A., Yang, M., \& RiceEvans, C. (1999). Antioxidant activity applying an improved ABTS radical cation decolorization assay. Free Radical Biology and Medicine, 26, 1231-1237.

Rizzello, C. G., Tagliazucchi, D., Babini, E., Rutella, G. S., Taneyo-Saa, D. L. T., \& Gianotti, A. (2016). Bioactive peptides from vegetable food matrices: research trends and novel biotechnologies for synthesis and recovery. Journal of Functional Foods, 27, 549-569.

Sánchez-Zapata, E., Fernández-López, J., Pérez-Alvarez, J. A., Soares, J., Sousa, S., Gomes, A. M. P., \& Pintado, M. M. E. (2013). In vitro evaluation of "horchata" co-products as carbon source for probiotic bacteria growth. Food and Bioproducts Processing, 91(3), 279-286.

Sentandreu, M. A., \& Toldra, F. (2006). A fluorescence-based protocol for quantifying angiotensin converting enzyme activity. Nature Protocols, 1(5), 2423-2427.

Setti, L., Scali, S., Degli Angeli, I., \& Pifferi, P. G. (1998). Horseradish peroxidase-catalysed oxidative coupling of 3-methyl 2benzothiazolinone hydrazone and methoxyphenols. Enzyme Microbial Technology, 22, 656-661.

Setti, L., Giuliani, S., Spinozzi, G., \& Pifferi, P. G. (1999). Laccasecatalyzed oxidative coupling of 3-methyl 2-benzothiazolinone hydrazone and methoxyphenols. Enzyme Microbial Technology, $25,285-289$

Sitanggang, A., Sinaga, W., Wie, F., Fernando, F., \& Krusong, W. (2019). Enhanced antioxidant activity of okara through solid state fermentation of GRAS fungi. Food Science and Technology, 40(1), $178-186$.

Subramaniam, S., Sabaratnam, V., Kuppusamy, U. R., \& Tan, Y. S. (2014). Solid-substrate fermentation of wheat grains by mycelia of 
indigenous species of the genus Ganoderma (higher basidiomycetes) to enhance the antioxidant activities. International Journal of Medicinal Mushrooms, 16, 259-267.

Taneyo-Saa, D. T., Di Silvestro, R., Nissen, L., Dinelli, G., \& Gianotti, A. (2018). Effect of sourdough fermentation and baking process severity on bioactive fiber compounds in immature and ripe wheat flour bread. $L W T, 89,322-328$.

Taneyo-Saa, D. T., Nissen, L., \& Gianotti, A. (2019). Metabolomic approach to study the impact of flour type and fermentation process on volatile profile of bakery products. Food Research International, $119,510-516$.

Tang, C. H., Wang, X. S., \& Yang, X. Q. (2009). Enzymatic hydrolysis of hemp (Cannabis sativa L.) protein isolate by various proteases and antioxidant properties of the resulting hydrolysates. Food Chemistry, 114, 1484-1490.

Taskin, M., Esim, N., \& Ortucu, S. (2012). Efficient production of Llactic acid from chicken feather protein hydrolysate and sugar beet molasses by the newly isolated Rhizopus oryzae TS-61. Food and Bioproduct Processing, 90, 773-779.

Teh, S., Niven, B. E., Bekhit, A. E. A., et al. (2014). The use of microwave and pulsed electric field as a pretreatment step in ultrasonic extraction of polyphenols from defatted hemp seed cake (Cannabis sativa) using response surface methodology. Food and Bioprocess Technology, 7, 3064-3076.

Tetlow, I. J., \& Emes, M. J. (2017). Starch biosynthesis in the developing endosperms of grasses and cereals. Agronomy, 7(4), 81. https://doi. org/10.3390/agronomy 7040081.

Torres-León, C., Ramírez-Guzman, N., Londoño-Hernandez, L., Martinez-Medina, G. A., Díaz-Herrera, R., Navarro-Macias, V., Alvarez-Pérez, O. B., Picazo, B., Villarreal-Vázquez, M., AscacioValdes, J., \& Aguilar, C. N. (2018). Food waste and byproducts: an opportunity to minimize malnutrition and hunger in developing countries. Frontiers in Sustainable Food Systems, 2, 52. https:// doi.org/10.3389/fsufs.2018.0005.

Treichel, H., de Oliveira, D., Mazutti, M. A., et al. (2010). A review on microbial lipases production. Food and Bioprocess Technology, 3, 182-196.

Wang, Q., \& Xiong, Y. L. (2019). Processing, nutrition, and functionality of Hempseed protein: a review. Comprehensive Reiews in Food Science and Food Safety, 18, 936-952.

Wiander, B., \& Korhonen, H. (2011). Preliminary studies on using LAB strains isolated from spontaneous sauerkraut fermentation in combination with mineral salt, herbs and spices in sauerkraut and sauerkraut juice fermentations. Agricultural and Food Science, 20(2), $175-181$

Wu, X., Jiang, S., Liu, M., Pan, L., Zheng, Z., \& Luo, S. (2011). Production of L-lactic acid by Rhizopus oryzae using semicontinuous fermentation in bioreactor. Journal of Industrial Microbiology and Biotechnology, 38, 565-671.

Yoo, H., Rheem, I., Rheem, S., \& Oh, S. (2018). Optimizing medium components for the maximum growth of Lactobacillus plantarum JNU 2116 using response surface methodology. Korean Journal for Food Science of Animal Resources, 38(2), 240-250.

Zhai, F. H., Wang, Q., \& Han, J. R. (2015). Nutritional components and antioxidant properties of seven kinds of cereals fermented by the basidiomycete Agaricus blazei. Journal of Cereal Science, 65, 202-208.

Zilly, A., dos Santos Bazanella, G. C., Helm, C. V., et al. (2012). Solidstate bioconversion of passion fruit waste by white-rot fungi for production of oxidative and hydrolytic enzymes. Food and Bioprocess Technology, 5, 1573-1580.

Publisher's Note Springer Nature remains neutral with regard to jurisdictional claims in published maps and institutional affiliations. 